\title{
The Effects of Seated Position on Occupant Kinematics in Low-speed Rear-end Impacts
}

\author{
Orion P. Keifer, Peter D. Layson, Bradley C. Reckamp \\ Applications Engineering Group, Inc.
}

Copyright @ 2005 SAE International

\begin{abstract}
Seventeen rear-end impacts with a nominal $8 \mathrm{~km} / \mathrm{hr}$ change in velocity to five human subjects in four positions were conducted. The four seated positions consisted of the Normal position, with the torso against the seat back, looking straight ahead, hands on the steering wheel, and feet on the floor; the Torso Lean position, with the torso leaned forward approximately 10 degrees away from the seat back; the Head Flex position, with the head flexed forward approximately 20 degrees from normal; and the Head Flex / Torso Lean position, with the head flexed forward approximately 20 degrees from normal and the torso leaned forward approximately 10 degrees from normal position. Relative to the Normal position, it was found that in both positions involving the torso lean, the peak head acceleration for the subject's head was reduced during the head-restraint impact. Further, the inertial acceleration of the head due to the forces on the neck, prior to the head rest impact, was somewhat higher for the two positions involving torso lean. Minor, transient, whiplash associated disorder (WAD) symptoms were noted. The nominal change in velocity used in this study appears to be of a reasonable magnitude to continue human subject out of position (OOP) testing.
\end{abstract}

\section{INTRODUCTION}

Human tolerance to force fields has been of interest to the scientific community for many years. Such information has been used in design of amusement park rides, to improve safety in sports, in automobile safety, and for military / space exploration applications. The work has been a combination of reconstructed accidents (such as falls where the forces can be easily calculated), cadaver and various human surrogate / anthropometric test device (ATD) studies, computer model studies, and human testing. Testing with human surrogates is advantageous in that the surrogate can be exposed to forces that may cause injury to human subjects. However, the extent that they are biofidelic to humans must be examined and verified.

In low speed impacts, the surrogates have not demonstrated biofidelic response. Therefore, human testing has been required (Szabo, et al. 1994). In particular, human testing in low-speed rear-end impacts has been conducted to better understand the mechanisms of injury, test improved seat designs, and to help develop human surrogates and computer models that are more biofidelic than those currently available. Human low-speed rear-end testing can be divided into two categories. The first are vehicle-to-vehicle / vehicleto-barrier impacts and the second are simulated impacts, generally using a test sled.

Specific human testing for vehicle-to-vehicle / vehicle-tobarrier low-speed rear-end impacts dates from the mid 1950's. Literature of these tests included work of Severy (1955), 2 exposures; West, et al. (1993), 45 exposures to 6 male subjects; McConnell, et al. (1993), 9 exposures to 4 male subjects; Siegmund, et al. (1994), 37 exposures to one female and four male subjects; Rosenbluth and Hicks (1994), 4 exposures to 2 male subjects; Szabo, et al. (1994), 7 exposures to 3 male and 2 female subjects; Bailey, et al. (1995), 26 exposures to one female and five male subjects; McConnell, et al. (1995), 18 exposures to 8 male subjects; SATAI tests (1995), 11 exposures; STAPP tests (1996), four exposures to 1 male and 1 female subjects; Szabo et al. (1996), 10 exposures to 4 male and 1 female subjects; Castro, et al. (1997), 17 exposures to 14 male and 5 female subjects; Brault, et al. (1998), 81 exposures to 21 male and 21 female subjects; and Anderson, et al. (1998), 18 exposures to 1 male subject. Additional unpublished data was reported by Szabo (1996) and Nielson (1996), which includes at least 55 exposures conducted by Baker Engineering, 18 exposures conducted by Maclnnis Engineering, 24 exposures by Szabo and Welcher, and 2 exposures by Texas Engineering Extension Services. There are undoubtedly additional exposures that are not published, such as 6 exposures previously conducted by Applications Engineering Group, Inc. (AEGI).

Simulated vehicle-to-vehicle human rear impact testing, using various test sleds includes the work of Mertz and Patrick (1967), at least 8 exposures to 1 male subject; Mertz and Patrick (1971), 46 exposures to 1 male subject; Siegmund and Williamson (1993), 8 exposures to 2 male subjects; Ono and Kanno (1993) 21 apparent exposures to each of 3 male subjects; Geigl, et al. (1994) 37 exposures to 23 male and 2 female subjects; 
Matsushita, et al. (1994), 19 exposures to 16 male and 3 female subjects; Kaneoka, et al. (1999) 10 exposures to 10 male subjects; and Watanabe, et al. (1999), 5 exposures to 1 male subject and 112 exposures to 4 male and 9 female subjects.

Human subject rear impact tests have to date been primarily conducted with human subjects restrained by a three point seat belt system, adopting a reasonably normal sitting position, with the torso against the seat back and head looking straight ahead. Some of the tests have, however, examined impacts with the occupant out of the normal seated position. McConnell et al. (1995) conducted one test $(\Delta \mathrm{V}=5.8 \mathrm{~km} / \mathrm{hr})$ with the volunteer's head turned to the left approximately 30 degrees, one test $(\Delta V=8.2 \mathrm{~km} / \mathrm{hr})$ with the volunteer's head turned to the left 45 degrees, and two exposures $(\Delta V=7.7 \mathrm{~km} / \mathrm{hr})$ with the human occupants unrestrained. West, et al. (1993) conducted one test $(6.4 \mathrm{~km} / \mathrm{hr}$ impact speed) with the subject leaning forward. Szabo (1994) conducted one test $(\Delta \mathrm{V} \cong 8 \mathrm{~km} / \mathrm{hr})$ with the subject adopting an increased head to head-restraint position. Matsushita, et al. (1994) conducted 4 tests ( $\Delta$ V's of 2.5, 3.5, 4.7 and $4.7 \mathrm{~km} / \mathrm{hr}$ ) with the subject's head rotated right or left, three tests $(\Delta V$ 's of $4.2,4.5$, and $4.8 \mathrm{~km} / \mathrm{hr}$ ) with the subject leaning forward, and one test ( $\Delta \mathrm{V}$ of $3.6 \mathrm{~km} / \mathrm{hr}$ ) with the subject bending laterally.

In the references above, the out of normal position impacts are not well documented and have not been compared to the motion and forces experienced from a relatively normal seating position. The purpose of this research is to compare the normal seated position resultant accelerations and time shifts, as measured by accelerometers on the subject's head and chest, with the same parameters measured in out of normal seated positions.

\section{TESTING}

\section{MATERIALS AND METHODS}

\section{Procedure}

The procedure was reviewed and approved by the Lynn University, Boca Raton, Florida, Institutional Review Board for Human Subject Testing. Aligned bumper-tobumper collisions between the front of a moving bullet vehicle and the rear bumper of a stationary target vehicle were used for this study. The bullet vehicle was rolled down a ramp from a predetermined height to produce a nominal $8 \mathrm{~km} / \mathrm{hr}$ change in velocity $(8 \mathrm{~km} / \mathrm{hr}$ $\Delta \mathrm{V}$ ) of the target vehicle. Measured target vehicle impact data is presented in Table 1. The subjects received up to four rear-end impacts, each of which was in a different seated position. The four seated positions were: Normal position $(\mathrm{N})$, with the test subject's head straight forward, torso against seat back, feet on the floor and hands at 2 and 10 o'clock on the steering wheel; the Torso Lean position (TL), with the subject in the normal position except with the subject leaning forward with a torso angle of approximately 10 degrees from the normal position; the Head Flex position (HF), with the subject in the normal position, except with the subject's head flexed forward approximately 20 degrees from the normal position; and the Head Flex / Torso Lean position (HF / TL), with the subject in the normal position except with the subject's head flexed forward approximately 20 degrees and with the subject's torso leaned forward approximately 10 degrees. The order of the impact positions for each subject was changed to reduce sequential bias in the data. Subsequent impact tests for a subject were conducted only after the subject reported that any significant whiplash associated disorder (WAD) symptoms had subsided. Furthermore, a minimum of four hours between tests was specified by the protocol. Each subject was requested to record and report any WAD symptoms.

\begin{tabular}{|c|c|c|c|c|}
\hline & $\begin{array}{c}\text { Target } \\
\text { Vehicle } \\
\Delta \mathrm{V} \\
(\mathrm{km} / \mathrm{hr})\end{array}$ & $\begin{array}{c}\text { Vehicle } \\
\text { Impact } \\
\text { Duration } \\
(\mathrm{s})\end{array}$ & $\begin{array}{c}\text { Impact } \\
\text { Peak Accel. } \\
(\mathrm{g} \text { 's })\end{array}$ & $\begin{array}{c}\text { Peak } \\
\text { Accel. } \\
\text { Delay } \\
(\mathrm{s})\end{array}$ \\
\hline Mean & 7.67 & 0.118 & 3.71 & 0.033 \\
\hline $\begin{array}{c}\text { Std. } \\
\text { Dev. }\end{array}$ & 0.18 & 0.004 & 0.372 & 0.016 \\
\hline
\end{tabular}

Table 1 Impact Data

\section{$\underline{\text { Subjects }}$}

The subjects include four males and one female with an average age of 43.8 years (standard deviation of 8.7 years). The subjects reported no significant back or neck pain, which required medical attention, for the proceeding 12 months, spinal surgery or hospitalization for a spinal related injury for the previous 36 months, or extraordinary headaches. They submitted to a cervical spine lateral X-ray for evaluation by a chiropractic physician to ensure no significant degenerative changes were present.

\section{Instrumentation}

Acceleration was sensed using Crossbow Technology, Inc. accelerometers (Crossbow Technology, Inc., $41 \mathrm{E}$. Daggett Drive, San Jose, CA 95134 (408) 965-3300), as follows: Two tri-axial 25-g (model CXL25FL3); one triaxial 50-g (model CXL50LP3); and two single axis 100-g (model CXL100LP1). These accelerometers have internal single pole Butterworth equivalent filtering with a $100 \mathrm{~Hz} 3 \mathrm{~dB}$ cutoff frequency.

The data was acquired at $1000 \mathrm{~Hz}$ and recorded using a National Instruments (model AT-MIO-16E-10) data acquisition card. The sensors were interfaced with the data acquisition system through a National Instruments SCXI 1300 terminal block attached to a SCXI 1100 processing block in a SCXI chassis. National Instruments LabVIEW ${ }^{\oplus}$ 5i data acquisition software was used for control and data recording. (National Instruments, 11500 North Mopac Expressway, Austin, TX. (512) 794-0100) 
A two slope ramp was constructed with the highest end approximately $2.4 \mathrm{~m}$ high. The upper portion of the ramp sloped downward at approximately 14.5 degrees for approximately $7.9 \mathrm{~m}$ and the lower portion of the ramp sloped downward at approximately 7.3 degrees for an additional $4.8 \mathrm{~m}$. The two-slope ramp reduced vertical bounce of the bullet vehicle due to changes in slope to the level test surface.

\section{Vehicle Preparation}

A 1984 Ford Escort (target vehicle) was selected to be impacted from the rear. The target vehicle was modified by removing the left (driver's side) front and rear doors to allow for video analysis of the driver. A bracket was attached to the driver's side on to which the Kodak Motion Corder Analyzer SR series high speed video camera was attached to monitor the driver motion. A Model 131A Conroflex ribbon switch (Tapeswitch Corporation, 100 Schmitt Boulevard, Farmingdale, NY 11735 , (631) 630-0442) was mounted on the lower rib of the target vehicle rear bumper. A photographic flash unit (generic) was wired in series with the tape switch and attached to the target vehicle center console, as a timing flash at impact for the video cameras. The positive terminal of the flash unit was used as a signal to the data acquisition system to synchronize the collected accelerometer data to the video data. The rear view mirrors were adjusted or removed to minimize the driver's visual clues of the impending impact. The installed seat was used; however, the original headrestraint was removed and a head-restraint was constructed that was vertically and longitudinally adjustable. A 50-g tri-axial accelerometer (Crossbow model CXL50LP3) was mounted on the floor of the target vehicle at its approximate center of gravity. Two 100-g uni-axial accelerometers (Crossbow model CXL100LP1) were mounted on the forward (inside) surface of the rear bumper, one on the left end and one on the right end. The passenger seat was removed and the computer systems for the high speed camera and the data acquisition system were installed.

A 1989 Chevrolet Corsica was selected for the impacting vehicle (bullet vehicle). To ensure bumper to bumper contact and to minimize damage with repeated impacts, a double bumper system was installed on the front of the bullet vehicle. Attached to the steel bumpers was a wood composite block made of $2 \times 10$ southern pine dimensioned lumber sheathed on the forward surface, with two layers of $3 / 4$ inch plywood. The wood was then covered with a closed cell foam block approximately 5 $\mathrm{cm}$ thick.

\section{Subject Preparation}

Adhesive targets were placed approximately over the left gleno-humeral joint, lateral left elbow, left wrist, and on the temple accelerometer, slightly above and behind the orbital angle of the left eye. The temple $25 \mathrm{~g}$ tri-axial accelerometer (Crossbow model CXL25LP3) was attached with adhesive tape on the left temple area of the subject and held in place with a headband strap, to approximate the center of mass of the subject's head in the sagittal plane. A chest $25 \mathrm{~g}$ tri-axial accelerometer (Crossbow model CXL25LP3) was attached with adhesive tape at the bottom of the subject's sternum and a halter strap was used to hold the accelerometer in place.

\section{$\underline{\text { Impact Protocol }}$}

The target vehicle was placed on a marked test surface, with the rear bumper face approximately 8 meters forward from the base of the ramp. The subject was first placed in the vehicle in a normal seated position. The seat was adjusted for the comfort of each of the test subjects, fully rearward for all four male subjects and fully forward for the female subject. The head-restraint was adjusted to a position between 4 and $5 \mathrm{~cm}$ behind the subject's opisthocranion, the most posterior protrusion of the head. The subject was moved into the appropriate predetermined position and asked to be as relaxed as possible while remaining in the position. The subject's torso lean angle and head flex angle was set using a two arm protractor. The protractor angle was preset, then one arm was aligned to the body segment in the normal position. The subject then moved the body segment to align with the preset second arm. For the Head Flex / Torso Lean position, the subject's head was flexed forward with the above procedure, then the subject's torso was leaned forward, while maintaining the same head-to-torso flex angle. A radio was played loudly to prevent any audio signals of the impending impact. The bullet vehicle was backed up the ramp to the predetermined position to produce an approximate 8 $\mathrm{km} / \mathrm{hr} \Delta \mathrm{V}$ of the target vehicle, placed in neutral, with the brake set. The bullet vehicle's brake was released with a delay of a few seconds to several minutes, to minimize the subject predicting when the impact would occur, and the bullet vehicle rolled down the ramp and into the rear of the target vehicle. Accelerometer, video and highspeed video data were collected for subsequent analysis. The speed change was calculated by integrating the vehicle center of gravity accelerometer data in the forward (X-axis) direction over the time of vehicle contact, as determined from the bumper tape switch.

\section{RESULTS}

Seventeen impacts were conducted on five of six test subjects. Test subject 2 elected to forgo rear-impact testing due to unresolved lower back pain from a back strain approximately one week prior to testing. The impacts had a mean change in velocity of $7.67 \mathrm{~km} / \mathrm{hr}$ (standard deviation of $0.18 \mathrm{~km} / \mathrm{hr}$ ).

The impact pulse was measured on the target vehicle center of gravity with a tri-axial $50-g$ accelerometer. Two uni-axial 100-g accelerometers were placed on the target rear bumper. A graph of the center of gravity and 
bumper mounted accelerometer data during a typical impact is presented in figure 1 . Target vehicle impact accelerometer data for all 17 tests are included in Appendix A.

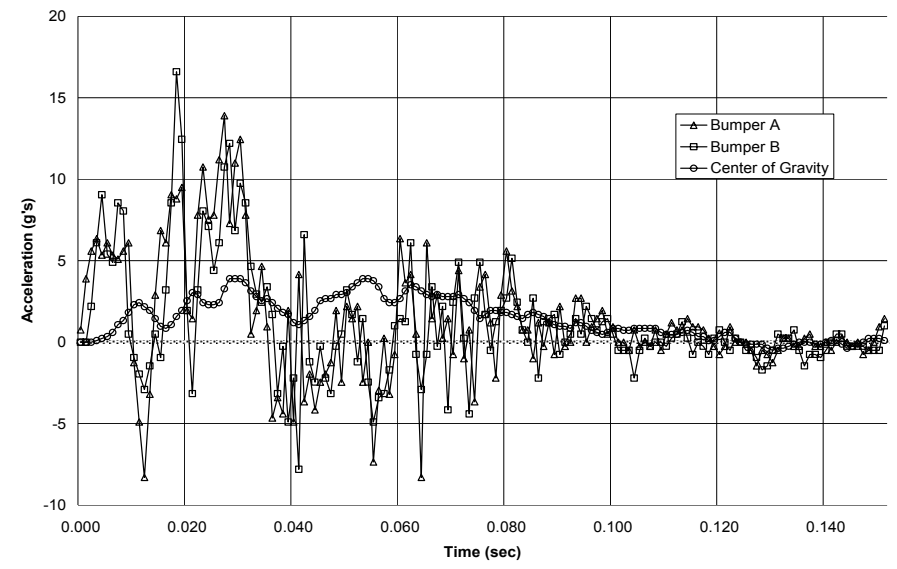

Figure 1 Target vehicle impact accelerations at $C G$ and rear bumper

Three of the test subjects (subject 1, 3, and 4) completed all four impact positions. Test subject 5 elected not to complete the final (Head Flex / Torso Lean) position and test subject 6 completed 2 impacts, Normal and Torso Lean, preplanned based on the subject's availability. The order of the pre-impact seated positions is presented in Table 2.

\begin{tabular}{|c|c|c|c|c|c|c|c|c|}
\hline \multirow[t]{2}{*}{ Sub } & \multirow[t]{2}{*}{ Gen } & \multirow{2}{*}{$\begin{array}{c}\text { Age } \\
(y r)\end{array}$} & \multirow{2}{*}{$\begin{array}{l}\mathrm{Ht} . \\
(\mathrm{cm})\end{array}$} & \multirow{2}{*}{$\begin{array}{l}\text { Wt. } \\
(\mathrm{Kg})\end{array}$} & \multicolumn{4}{|c|}{ Order of positions } \\
\hline & & & & & $\begin{array}{l}1^{\text {st }} \\
\text { Imp }\end{array}$ & $\begin{array}{l}2^{\text {nd }} \\
\text { Imp }\end{array}$ & $\begin{array}{l}3^{\text {rd }} \\
I m p\end{array}$ & $\begin{array}{l}4^{\text {th }} \\
\operatorname{Imp}\end{array}$ \\
\hline 1 & M & 49 & 188 & 107 & $\begin{array}{l}\mathrm{HF} \\
/ \mathrm{TL}\end{array}$ & $\mathrm{HF}$ & TL & $\mathrm{N}$ \\
\hline 3 & M & 32 & 167 & 77 & $\mathrm{TL}$ & $\mathrm{N}$ & $\begin{array}{c}\mathrm{HF} \\
/ \mathrm{TL}\end{array}$ & $\mathrm{HF}$ \\
\hline 4 & $\mathrm{~F}$ & 41 & 153 & 56 & $\mathrm{~N}$ & $\begin{array}{l}\mathrm{HF} \\
/ \mathrm{TL}\end{array}$ & $\mathrm{HF}$ & TL \\
\hline 5 & M & 42 & 173 & 73 & $\mathrm{HF}$ & TL & $\mathrm{N}$ & \\
\hline 6 & M & 55 & 191 & 130 & TL & $\mathrm{N}$ & & \\
\hline \multicolumn{2}{|c|}{ Mean } & 43.8 & 174.4 & 88.6 & & & & \\
\hline \multicolumn{2}{|c|}{$\begin{array}{l}\text { Standard } \\
\text { Deviation }\end{array}$} & 8.7 & 15.6 & 29.6 & & & & \\
\hline
\end{tabular}

Table 2 Subject Data / Impact Order

The head X-axis (forward) and Z-axis (vertical) acceleration data for each test was vectorially combined to produce a combined acceleration and angle of acceleration. Figure 2 shows the comparison of head combined acceleration data as a function of time after initial impact for test subject 1 for the four seated positions. As can be seen, the head acceleration plots are quite similar for the Normal (N) and Head Flex (HF) positions. The Torso Lean (TL) and Head Flex / Torso Lean (HF / TL) have lower head restraint impact peaks and the peaks are delayed. The combined sagittal plane head and chest acceleration data for all 5 subjects are included in Appendix B.

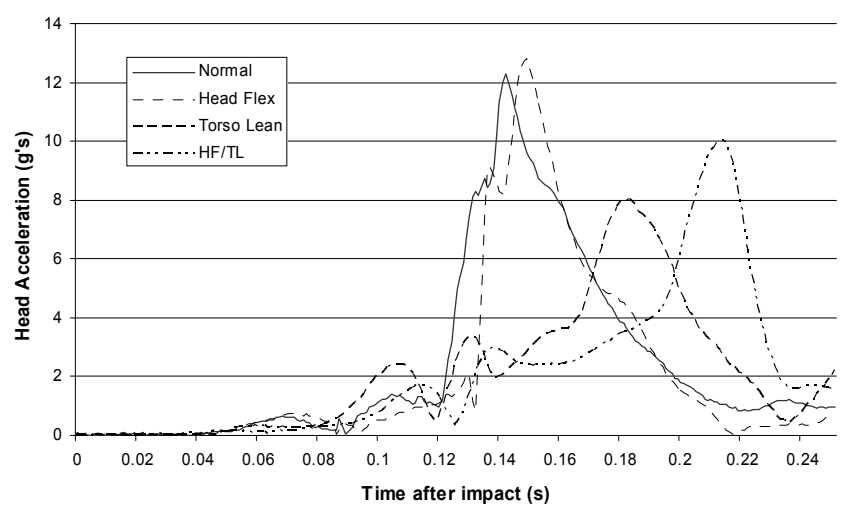

Figure 2 Combined Sagittal Plane Head Acceleration

For numerical analysis and comparison, three acceleration parameters were used. First, the peak chest acceleration and the time delay from initial impact that the peak chest acceleration occurred. Second, the peak inertial head acceleration (the highest head acceleration prior to the subject's head contacting the head-restraint) and the time delay from initial impact to peak inertial head acceleration. Third, the peak headrestraint impact acceleration and time delay from initial impact to peak head restraint impact acceleration. Statistical comparison between parameters measured for each of the positions was conducted using f-tests.

\begin{tabular}{|c|c|c|c|c|c|c|c|}
\hline \multirow[t]{2}{*}{ Pos. } & \multirow[t]{2}{*}{$\mathrm{n}$} & & \multirow[t]{2}{*}{ Mean } & \multirow{2}{*}{$\begin{array}{c}\text { Stand } \\
\text { Dev } \\
\text { (SD) }\end{array}$} & \multicolumn{3}{|c|}{$\begin{array}{c}\text { Statistical Comparison } \\
\text { ( } p \text { value) }\end{array}$} \\
\hline & & & & & $N$ & $\mathrm{HF}$ & $\mathrm{TL}$ \\
\hline \multirow[t]{2}{*}{$N$} & \multirow[t]{2}{*}{5} & $\begin{array}{c}\text { Accel. } \\
\text { (g's) }\end{array}$ & 5.804 & 0.462 & & & \\
\hline & & $\begin{array}{l}\text { Delay } \\
\text { (s) }\end{array}$ & 0.137 & 0.017 & & & \\
\hline \multirow[t]{2}{*}{$\mathrm{HF}$} & \multirow[t]{2}{*}{4} & $\begin{array}{l}\text { Accel. } \\
\text { (g's) }\end{array}$ & 5.528 & 0.123 & 0.144 & & \\
\hline & & $\begin{array}{l}\text { Delay } \\
\text { (s) }\end{array}$ & 0.165 & 0.004 & 0.008 & & \\
\hline \multirow[t]{2}{*}{ TL } & \multirow[t]{2}{*}{5} & $\begin{array}{l}\text { Accel. } \\
\text { (g's) }\end{array}$ & 6.992 & 0.963 & 0.019 & 0.010 & \\
\hline & & $\begin{array}{c}\text { Delay } \\
\text { (s) }\end{array}$ & 0.151 & 0.018 & 0.121 & 0.089 & \\
\hline \multirow{2}{*}{$\begin{array}{l}\mathrm{HF} / \\
\mathrm{TL}\end{array}$} & \multirow[t]{2}{*}{3} & $\begin{array}{l}\text { Accel. } \\
\text { (g's) }\end{array}$ & 5.370 & 0.477 & 0.125 & 0.271 & 0.019 \\
\hline & & $\begin{array}{c}\text { Delay } \\
\text { (s) }\end{array}$ & 0.142 & 0.031 & 0.386 & 0.095 & 0.307 \\
\hline
\end{tabular}

Table 3 Peak Chest Acceleration

As Table 3 shows, the Torso Lean position, a normal position with the torso leaned forward approximately 10 degrees, has a peak chest acceleration that is significantly higher $(p<0.05)$ than the other three positions. The time delay from the impact to the peak chest acceleration for the Head Flex position is significantly longer $(p<0.05)$ than for the Normal position.

As can be seen in Table 4, the peak head acceleration from the impact with the head-restraint was significantly higher $(p<0.05)$ for the Head Flex position than from either the Torso Lean or Head Flex / Torso Lean position. The time delay of the peak acceleration from the Head Flex / Torso Lean impact was significantly 
longer $(p<0.05)$ than for the Normal or Head Flex position and the Torso Lean position delay was also significantly longer $(p<0.05)$ than the Normal position.

\begin{tabular}{|c|c|c|c|c|c|c|c|}
\hline \multirow[t]{2}{*}{ Pos } & \multirow[t]{2}{*}{$\mathrm{n}$} & & \multirow[t]{2}{*}{ Mean } & \multirow{2}{*}{$\begin{array}{l}\text { Stand } \\
\text { Dev } \\
\text { (SD) }\end{array}$} & \multicolumn{3}{|c|}{$\begin{array}{l}\text { Statistical Comparison } \\
\text { ( } p \text { value) }\end{array}$} \\
\hline & & & & & $\mathrm{N}$ & $\mathrm{HF}$ & $\mathrm{TL}$ \\
\hline \multirow[t]{2}{*}{$\mathrm{N}$} & \multirow[t]{2}{*}{5} & $\begin{array}{l}\text { Accel. } \\
\text { (g's) }\end{array}$ & 11.497 & 3.637 & & & \\
\hline & & $\begin{array}{l}\text { Delay } \\
\text { (s) }\end{array}$ & 0.131 & 0.024 & & & \\
\hline \multirow[t]{2}{*}{$\mathrm{HF}$} & \multirow[t]{2}{*}{4} & $\begin{array}{c}\text { Accel. } \\
\text { (g's) }\end{array}$ & 13.467 & 0.570 & 0.270 & & \\
\hline & & $\begin{array}{l}\text { Delay } \\
\text { (s) }\end{array}$ & 0.146 & 0.012 & 0.148 & & \\
\hline \multirow[t]{2}{*}{ TL } & \multirow[t]{2}{*}{5} & $\begin{array}{l}\text { Accel. } \\
\text { (g's) }\end{array}$ & 9.586 & 2.760 & 0.188 & 0.015 & \\
\hline & & $\begin{array}{l}\text { Delay } \\
\text { (s) }\end{array}$ & 0.167 & 0.035 & 0.047 & 0.147 & \\
\hline \multirow{2}{*}{$\begin{array}{l}\mathrm{HF} / \\
\mathrm{TL}\end{array}$} & \multirow[t]{2}{*}{3} & $\begin{array}{l}\text { Accel. } \\
\text { (g's) }\end{array}$ & 9.208 & 2.992 & 0.198 & 0.018 & 0.431 \\
\hline & & $\begin{array}{l}\text { Delay } \\
\text { (s) }\end{array}$ & 0.182 & 0.031 & 0.019 & 0.041 & 0.282 \\
\hline
\end{tabular}

Table 4 Peak Head Acceleration (from head restraint impact)

\begin{tabular}{|c|c|c|c|c|c|c|c|}
\hline \multirow[t]{2}{*}{ Pos } & \multirow[t]{2}{*}{$n$} & & \multirow[t]{2}{*}{ Mean } & \multirow{2}{*}{$\begin{array}{l}\text { Stand } \\
\text { Dev } \\
\text { (SD) }\end{array}$} & \multicolumn{3}{|c|}{$\begin{array}{l}\text { Statistical Comparison } \\
\text { ( } p \text { value) }\end{array}$} \\
\hline & & & & & $\mathrm{N}$ & $\mathrm{HF}$ & $\mathrm{TL}$ \\
\hline \multirow[t]{2}{*}{$\mathrm{N}$} & \multirow[t]{2}{*}{5} & $\begin{array}{l}\text { Accel. } \\
\text { (g's) }\end{array}$ & 1.096 & 0.376 & & & \\
\hline & & $\begin{array}{l}\text { Delay } \\
\text { (s) }\end{array}$ & 0.069 & 0.059 & & & \\
\hline \multirow[t]{2}{*}{$\mathrm{HF}$} & \multirow[t]{2}{*}{4} & $\begin{array}{c}\text { Accel. } \\
\text { (g's) }\end{array}$ & 1.458 & 0.588 & 0.160 & & \\
\hline & & $\begin{array}{l}\text { Delay } \\
\text { (s) }\end{array}$ & 0.059 & 0.025 & 0.397 & & \\
\hline \multirow[t]{2}{*}{ TL } & \multirow[t]{2}{*}{5} & $\begin{array}{l}\text { Accel. } \\
\text { (g's) }\end{array}$ & 2.086 & 1.123 & 0.049 & 0.206 & \\
\hline & & $\begin{array}{l}\text { Delay } \\
\text { (s) }\end{array}$ & 0.073 & 0.027 & 0.447 & 0.337 & \\
\hline \multirow{2}{*}{$\begin{array}{c}\mathrm{HF} / \\
\mathrm{TL}\end{array}$} & \multirow[t]{2}{*}{3} & $\begin{array}{l}\text { Accel. } \\
\text { (g's) }\end{array}$ & 1.636 & 1.179 & 0.180 & 0.413 & 0.304 \\
\hline & & $\begin{array}{l}\text { Delay } \\
\text { (s) }\end{array}$ & 0.069 & 0.025 & 0.500 & 0.425 & 0.247 \\
\hline
\end{tabular}

Table 5 Peak Inertial Head Acceleration (Prior to head restraint impact)

The peak inertial head acceleration data (acceleration prior to the head restraint impact) was quite variable, as can be seen from Table 5; however, the peak head inertial acceleration in the Torso Lean position was significantly higher $(p<0.05)$ than for the Normal position.

A post-hoc comparison of the peak chest acceleration and delay of the peak to that of the target vehicle is included in Table 6 . The peak acceleration of the subject's chest is significantly greater $(p<0.05)$ than the peak acceleration at the center of gravity of the target vehicle. Further, the peak acceleration occurred significantly later $(p<0.05)$ for the subject's chest than the center of gravity for the vehicle.

\begin{tabular}{|c|c|c|c|c|c|}
\hline & $\mathrm{n}$ & Parameter & Mean & $\begin{array}{c}\text { Stand } \\
\text { Dev } \\
\text { (SD) }\end{array}$ & $\begin{array}{c}\text { Statistical } \\
\text { Com- } \\
\text { parison }\end{array}$ \\
\hline $\begin{array}{c}\text { Vehicle } \\
\text { Center of } \\
\text { Gravity }\end{array}$ & 17 & $\begin{array}{c}\text { Peak } \\
\text { Accel. } \\
\text { (g's) }\end{array}$ & 3.711 & 0.372 & \\
\cline { 3 - 6 } & Delay (s) & 0.033 & 0.016 & \\
\hline $\begin{array}{c}\text { Subject } \\
\text { Chest }\end{array}$ & 17 & $\begin{array}{c}\text { Peak } \\
\text { Accel. } \\
\text { (g's) }\end{array}$ & 6.012 & 0.875 & $\mathrm{p}<0.001$ \\
\cline { 2 - 6 } & Delay (s) & 0.151 & 0.021 & $\mathrm{p}<0.001$ \\
\hline
\end{tabular}

Table 6 Peak Delay Comparison

\section{Whiplash Associated Disorder (WAD) Symptoms}

Subjective symptoms were self-recorded and selfreported by each subject. The reported symptoms are summarized in Table 7.

\begin{tabular}{|c|c|c|}
\hline Subj & Pos & Symtoms \\
\hline 1 & $\mathrm{HF} / \mathrm{T}$ & $\begin{array}{l}\text { - transient headache lasting approx. 5s } \\
\text { - shoulder tightness lasting }<2 \mathrm{~h}\end{array}$ \\
\hline 1 & $\mathrm{HF}$ & $\begin{array}{l}\text { - transient headache lasting approx. } \\
10 \text { s } \\
\text { - shoulder tightness/soreness lasting } \\
<24 \mathrm{~h} \\
\text { - occasional twinge of neck discomfort } \\
<48 \mathrm{~h}\end{array}$ \\
\hline 1 & TL & - shoulder tightness lasting $<24 \mathrm{~h}$ \\
\hline 1 & $\mathrm{~N}$ & $\begin{array}{l}\text { - shoulder tightness/soreness lasting } \\
<24 \mathrm{~h}\end{array}$ \\
\hline 3 & TL & None \\
\hline 3 & $\mathrm{~N}$ & None \\
\hline 3 & $\begin{array}{l}\mathrm{HF} / \mathrm{T} \\
\mathrm{L}\end{array}$ & None \\
\hline 3 & $\mathrm{HF}$ & $\begin{array}{l}\text { - transient headache lasting approx. } \\
15 \mathrm{~s}\end{array}$ \\
\hline 4 & $\mathrm{~N}$ & None \\
\hline 4 & $\begin{array}{l}\mathrm{HF} / \mathrm{T} \\
\mathrm{L}\end{array}$ & $\begin{array}{l}\text { - mild transient headache lasting }<2 \mathrm{~h} \\
\text { - stiff neck next day lasting }<24 \mathrm{~h}\end{array}$ \\
\hline 4 & $\mathrm{HF}$ & None \\
\hline 4 & TL & None \\
\hline 5 & HF & $\begin{array}{l}\text { - mild frontal headache lasting a few s. } \\
\text { - pain in back of head lasting few h. }\end{array}$ \\
\hline 5 & TL & $\begin{array}{l}\text { - dull compression pain at base of skull } \\
\text { for a few days and intermittent for } 2 \\
\text { weeks } \\
\text { - pain in back of head lasting few h. }\end{array}$ \\
\hline 5 & $\mathrm{~N}$ & $\begin{array}{l}\text { - slight exacerbation of dull } \\
\text { compression pain at base of skull } \\
\text { - elected to forgo } 4^{\text {th }} \text { impact }\end{array}$ \\
\hline 6 & TL & $\begin{array}{l}\text { - slight exacerbation of previously } \\
\text { pulled forearm muscle lasting }<1 \mathrm{~m}\end{array}$ \\
\hline 6 & $\mathrm{~N}$ & $\begin{array}{l}\text { - slight exacerbation of previously } \\
\text { pulled forearm muscle lasting }<1 \mathrm{~m}\end{array}$ \\
\hline
\end{tabular}

Table 7 Self-reported WAD symptoms

Follow-up surveys were conducted three years after the test exposures. All participants reported no additional symptoms of WAD subsequent to those reported above. 


\section{DISCUSSION}

Notably, the two torso leaning positions (Torso Lean and Head Flex / Torso Lean) had a somewhat higher head peak inertial acceleration and a lower head restraint impact peak acceleration of the subjects' head. Therefore, the testing shows that a significantly greater amount of the velocity change of the subject's head in these positions occurs as the neck accelerates the head forward prior to the head-restraint impact. In other words, a greater amount of the velocity change was caused by the forces in the neck and less is "saved" for the impact with the head-restraint. It appears that the subject's back / neck / head complex does not simply rotate rearward at the hips until the subject's back reaches a relatively normal torso position, at which time the acceleration of the shoulders begin, followed by the neck and then the head. The noted acceleration of the head before the upper back reaches the seatback is thought to be due to the visco-elastic effect of the motion of the torso, as it reclines, combined with the rolling of the subjects back from bottom to top into the seatback. Regardless of the reason, it appears that the forces on the neck due to the inertia of the head occur over a longer period of time.

The Head Flex position when compared to the Normal position did produce higher mean peak acceleration of the head impacting into the head-restraint, with a somewhat higher peak acceleration of the head during the inertial phase. This would suggest that the headrestraint location closer to the head produces lower head-restraint impact acceleration as well as reduced inertial acceleration of the head. The recommendation by the Insurance Institute for Highway Safety that the head-restraint location be within $5 \mathrm{~cm}$ of the rear of the subject's head and above the top of the subject's head, appears to lower both the inertial acceleration (and forces on the subject's neck) and the peak impact acceleration due to the head-restraint. The head restraint impact acceleration pulse would of course have to be broader to achieve the required change in velocity of the head. Intuitively, one would expect that a headrestraint that was closer to the subject's head would provide better coupling between the acceleration of the head-restraint and the subject's head and reduce both the inertial and head-restraint impact peak accelerations of the subject's head.

All subjects rated the Normal position as clearly the mildest impact position. The three subjects who experienced the Head Flex / Torso Lean position rated it as clearly the most severe. The other positions were rated in between with 3 of 4 subjects rating the Torso Lean position and 1 of 4 rating the Neck Flex position as the more severe of the two.

The nominal change in velocity used in this study appears to be of a reasonable magnitude to continue human subject out of position (OOP) testing.
The subjects in this test cover a wide spectrum of sizes, from an over $95^{\text {th }}$ percentile male to a less than $10^{\text {th }}$ percentile female. One would expect this large of a variation of height and weight to cause remarkable variations in the kinematics of the subjects. After viewing the high speed video of the occupants, several observations were made. In several cases, a shoulder shrug, the lifting of the subject's two shoulders, appeared approximately 150 to 200 milliseconds after the impact and was not noted in previous literature. This shoulder shrug phenomenon appears to be an autonomic reaction and may account for the stiffness and soreness of the shoulders of some subjects after the impacts. Second, the female subject (weight $56 \mathrm{~kg}$ ) did not flex the seat back as far as the heavier subjects. There also appeared to be significantly greater rebound from the seat by the lightest subject.

One of the subjects (subject 3 ) inadvertently neglected to wear a seatbelt in the Torso Lean position (his first impact). Evaluation of the high speed video demonstrates that the seatback rebound did not cause his body to move measurably forward of his initial seat position. This is consistent with previous data as reported by Szabo, et al. (1994) and McConnell, et al. (1995). In view of the apparently greater rebound for subject 4 (approximate $10^{\text {th }}$ percentile female) in our test, as discussed above, the effect of seat rebound in rear-end impacts based on subject size is an area for further research.

The modification to the bullet vehicle's bumper potentially affected the impact pulse; however, the pulse shape was grossly similar between impacts and duration of the pulses were grouped very tightly with a mean of 0.118 seconds and a standard deviation of 0.004 seconds. The pulse duration of these tests are consistent with previous testing without bumper modification. For example, Cipriani (2002) reported impact pulse durations between 0.098 to 0.215 seconds for 30 full-scale low-speed bumper to bumper impacts.

Use of the Crossbow accelerometers with a $1000 \mathrm{~Hz}$ sample rate and without further filtering has proved to provide adequate velocity and positional results in other crash testing. For example, a high speed test with a change in velocity of over $45 \mathrm{~km} / \mathrm{h}$ and a post-impact travel of over $90 \mathrm{~m}$, double integration, without further processing, resulted in a positional error of less than $5 \%$.

\section{CONCLUSIONS}

1. In this study, the peak head acceleration upon headrestraint impact by the subjects' heads was significantly less when the subject's torso was leaned forward (Torso Lean and Head Flex/ Torso Lean Positions) as compared with the Head Flex position and somewhat less as compared to the Normal position.

2. In this study, the peak chest acceleration was significantly higher for the Torso Lean position than 
the other three positions and the delay to the peak chest acceleration was significantly longer for the Torso Lean position as compared to the Normal position.

3. The nominal $8 \mathrm{~km} / \mathrm{h}$ change in velocity used in this study appears to be of a reasonable magnitude to continue human subject out of position (OOP) testing.

\section{ACKNOWLEDGMENTS}

The authors would like to extend special thanks to Jud Welcher and Thomas Heilmann for their astute critique and assistance in this work and to Dr. John A. Davenport for his chiropractic examinations of the subjects during the testing.

\section{REFERENCES}

1. Anderson, R.D., Welcher, J.B., Szabo, T.J., Eubanks, J.J., Haight, W.R., 1998. Effect of braking on human occupant and vehicle kinematics in low speed rear-end collisions. Society of Automotive Engineers (SAE No. 980298).

2. Bailey, M.N., Wong, B.C., Lawrence, J.M., 1995. Data and methods for estimating the severity of minor impacts. Society of Automotive Engineers (SAE No. 950352).

3. Biomechanical Research and Testing, LLC, 1996. Tests conducted June 14, and July 14, 1996.

4. Brault, J.R., Wheeler, J.B., Siegnumd, G.P., Brault, E.J., 1998. Clinical response of human subjects to rear-end automobile collisions. Archives of Physical Medicine and Rehabilitation, 79, 72-80.

5. Castro, W.H.M., Schilgen, M., Meyer, S., Weber, M., Peuker, C., Wortler, K., 1997. Do 'whiplash injuries' occur in low-speed rear impacts? European Spine Journal 6, 366-75.

6. Cipriani, A.L., Bayan, F.P., Woodhouse, M.L., Cornetto, A.D., Dalton, A.P., Tanner, C.B., Timbario, T.A., Deyerl, E.S., 2002, Low Speed Collinear Impact Severity: A Comparison between Full Scale Testing and Analytical Prediction Tools with Restitution Analysis, Society of Automotive Engineers (SAE No. 2002-01-0540)

7. Geigl, B.C., Steffan, H., Leinzinger, P., Roll, P., Muhlbauer, M., Bauer, G., 1994. The movement of the head and cervical spine during rear-end impact. Proceedings of 1994 International IRCOBI Conference on the Biomechanics of Impacts, 127137.

8. Kaneoka, K., Ono, K., Inami, S., Hayash, K., 1999. Motion analysis of cervical vertebrae during whiplash loading. Spine 24, 763-770.

9. Kumar, S., Narayan, Y., Amell, T., 2000. Role of awareness in head-neck acceleration in low velocity rear-end Impacts. Accident Analysis and Prevention 32, 233-241.
10. Matsushita, T., Sato, T.B., Hirabayashi, K., Fujimura, S., Asazuma, T., Takatori, T., 1994. X-ray study of the human neck motion due to head inertia loading. Proceedings of the 38th STAPP Car Crash Conference, Society of Automotive Engineer (SAE No. 942208), 55-64.

11. McConnell, W.E., Howard, R.P., Guzman, H.M., Bomar, J.B., Raddin, J.H., Benedict, J.V., Smith, H.L., Hatsell, C.P., 1993. Analysis of human test subject kinematic responses to low velocity rear-end impacts. Society of Automotive Engineers (SAE No. 930889).

12. McConnell, W.E., Howard, R.P., Krause, R., Guzman, H.M., Bomar, J.B., Raddin, J.H., Benedict, J.V., Hatsell, C.P., 1995. Human head and neck kinematics after low velocity rear-end impacts understanding 'whiplash'. Society of Automotive Engineers (SAE No. 952724).

13. Mertz, H.J., Patrick, L.M., 1967. Investigation of the kinematics and kinetics of whiplash. Society of Automotive Engineers (SAE No. 670919).

14. Mertz, H.J., Patrick, L.M., $1971 . \quad$ Strength and response of the human neck. Society of Automotive Engineers (SAE No. 710855).

15. Nielson, G.P., Gough, J.P., Little, D.M., West, D.H., Baker, V.T., 1996. Low speed rear impact test summary - human test subjects. Accident Reconstruction Journal 47, 40-43.

16. Nielsen, G.P., Little, D.M., West, D.H., Baker, V.T., 1997. Human subject responses to repeated low speed impacts using utility vehicles. Society of Automotive Engineers (SAE No. 97039).

17. Ono, K., Kanno, M., 1993. Influences of the physical parameters on the risk to neck injuries in low impact speed rear-end collisions. Proceedings of 1993 International IRCOBI Conference on the Biomechanics of Impacts, 201-212.

18. Rosenbluth, W., Hicks, L., 1994. Evaluating lowspeed rear-end impact severity and resultant occupant stress parameters. Journal of Forensic Science 39, 1393-1424.

19. SATAI (Southwestern Association of Technical Accident Investigators), 1995. Test conducted by Maclnnis Engineering Associates, LTD., Phoenix, AZ meeting, July 20-21, 1995.

20. Severy, D.M., Mathewson, J.H., Bechtol, D.O., 1955. Controlled automobile rear-end collisions, an investigation of related engineering and medical phenomena. Canadian Services Medical Journal 7, 727-759.

21. Siegmund, G.P., Williamson, P.B., 1993. Speed change $(\Delta \mathrm{V})$ of amusement park bumper cars. Proceedings of the Canadian Multidisciplinary Road Safety Conference VIII, June 14-16, 1993.

22. Siegmund, G.P., Bailey, M.N., King, D.J., 1994. Characteristics of specific automobile bumpers in low-velocity impacts. Society of Automotive Engineers (SAE No. 940916).

23. STAPP Car Crash Conference, 1996. Tests conducted February 3-4 1996. 
24. Szabo, T.J., Welcher, J.B., Anderson, R.A., Rice, M.M., Ward, J.A., Paulo, L.R., Carpenter, N.J., 1994. Human occupant kinematic response to low speed rear-end impacts. Society of Automotive Engineers (SAE No. 940532).

25. Szabo, T.J., Welcher, J.B., 1996. Human subject kinematics and electromyographic activity during low speed rear-end impacts. Society of Automotive Engineers (SAE No. 962432).

26. Texas Engineering Extension Services, 1996. Course on Analysis of Low Speed Collisions, May 9, 1996.

27. West, D.H., Gough, J.P., Harper, G.T.K., 1993. Low speed rear-end collision testing using human subjects. Accident Reconstruction Journal 5, 319327.

\section{CONTACT}

Orion P. Keifer, P.E., Principal Mechanical Engineer

Peter D. Layson, Principal Staff Scientist

Bradley C. Reckamp, P.E., Senior Mechanical Engineer Applications Engineering Group, Inc.

1200 Mayport Road, Atlantic Beach, Florida 32233

(800) 777-7668

aegi@aegiforensics.com 


\section{APPENDIX A}

Target vehicle accelerometer data.

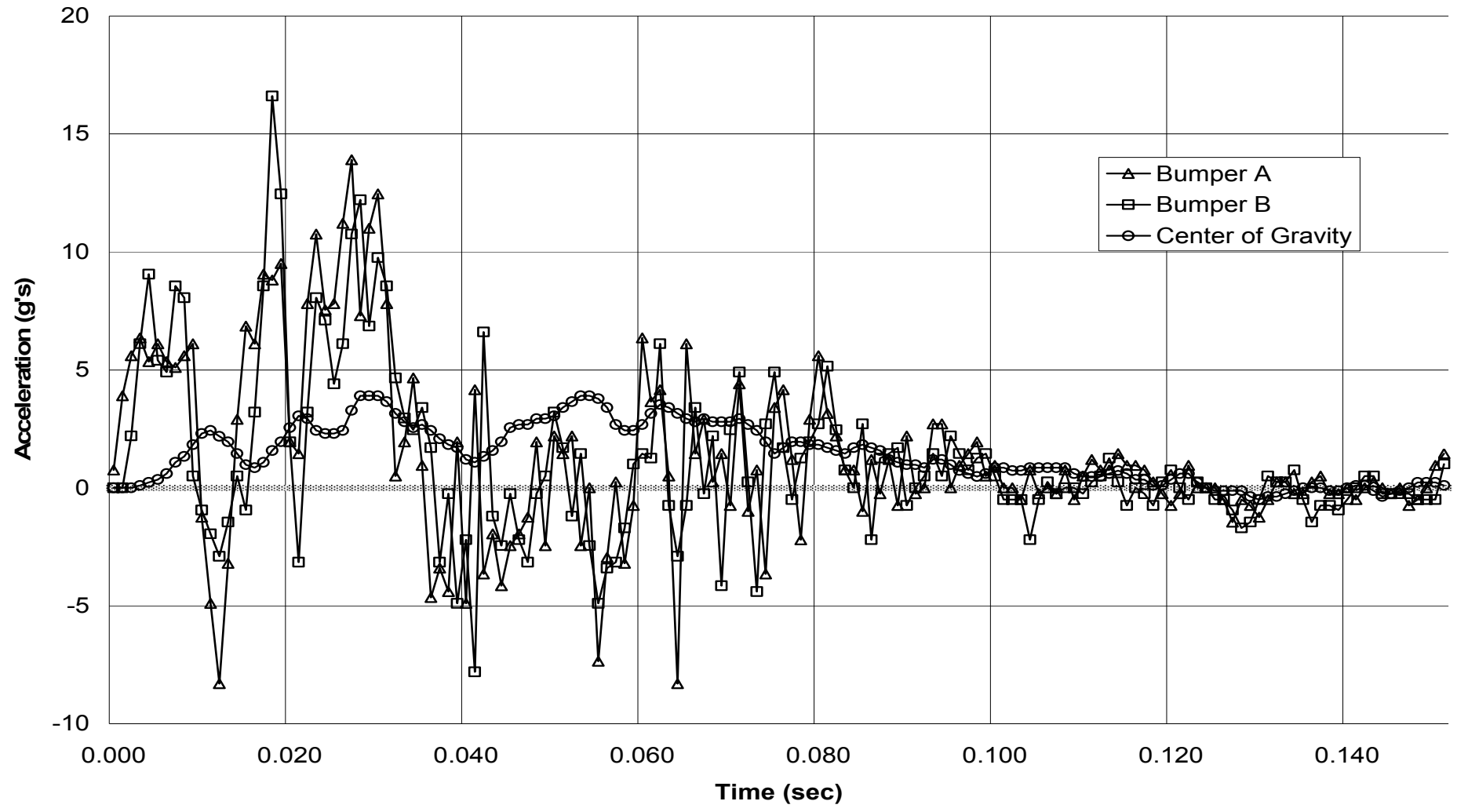

Figure 1-A Subject 1, test 1 (Head Flex / Torso Lean)

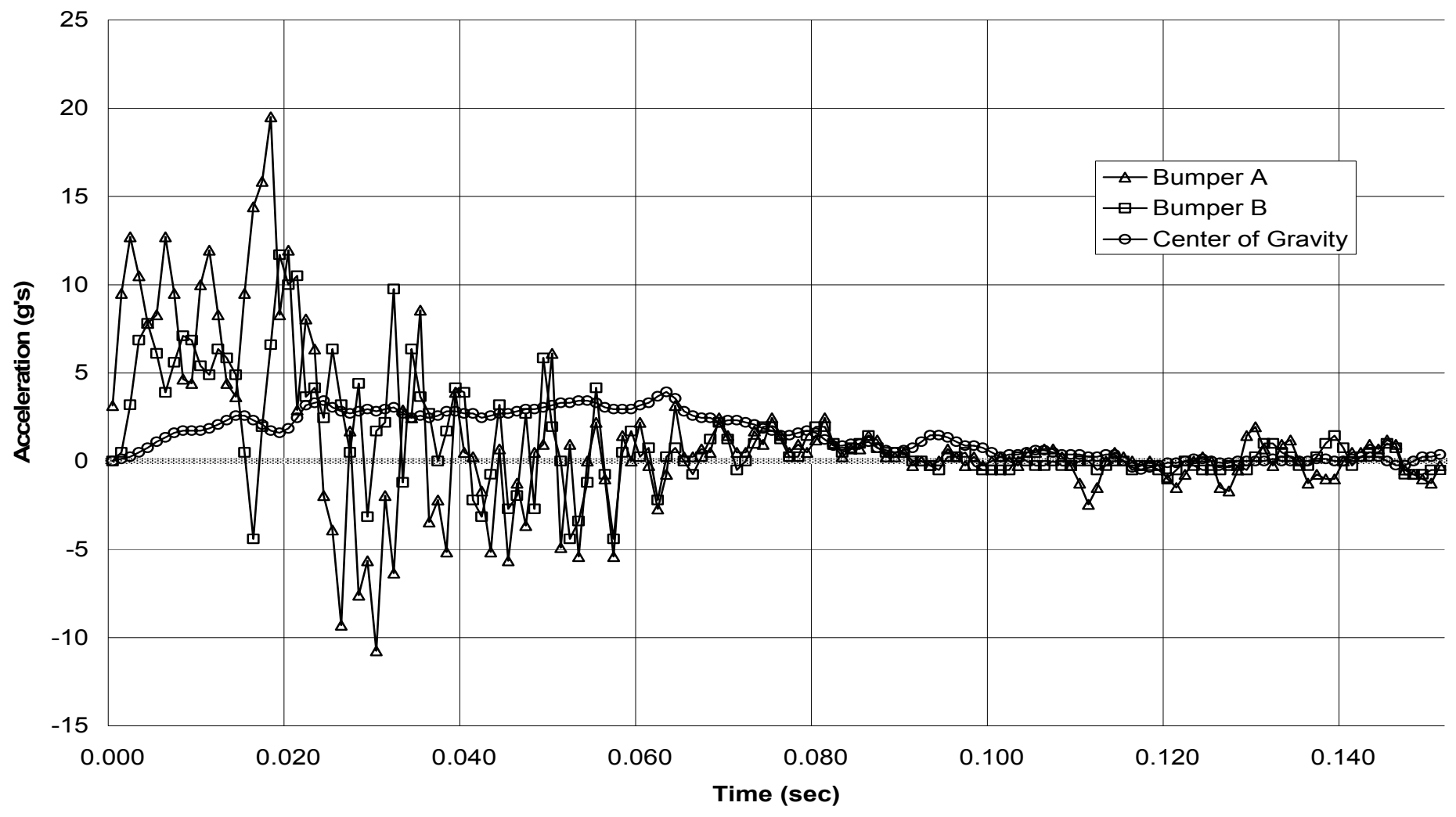

Figure 2-A Subject 1, test 2 (Head Flex) 


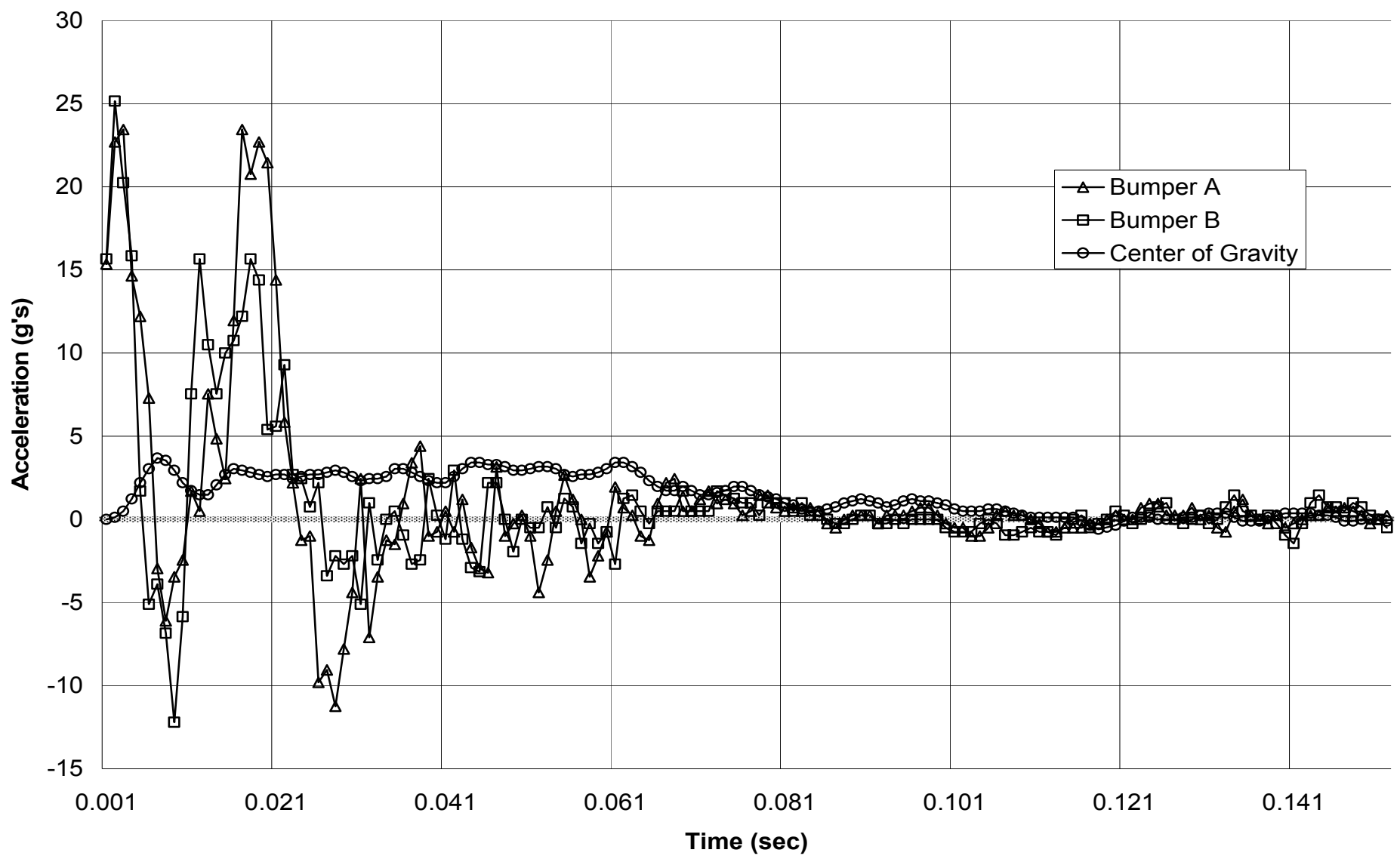

Figure 3-A Subject 1, test 3 (Torso Lean)

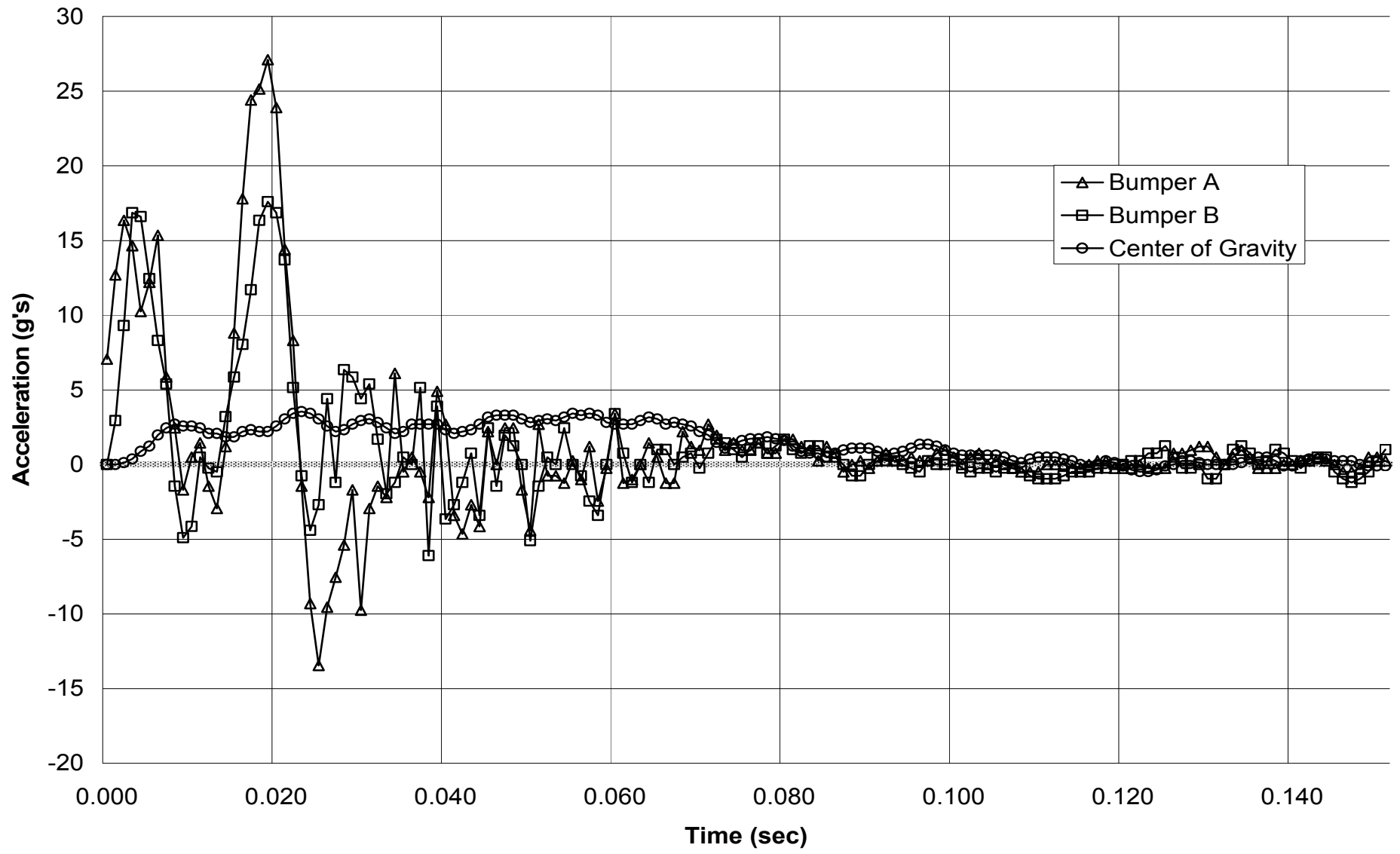

Figure 4-A Subject 1, test 4 (Normal) 


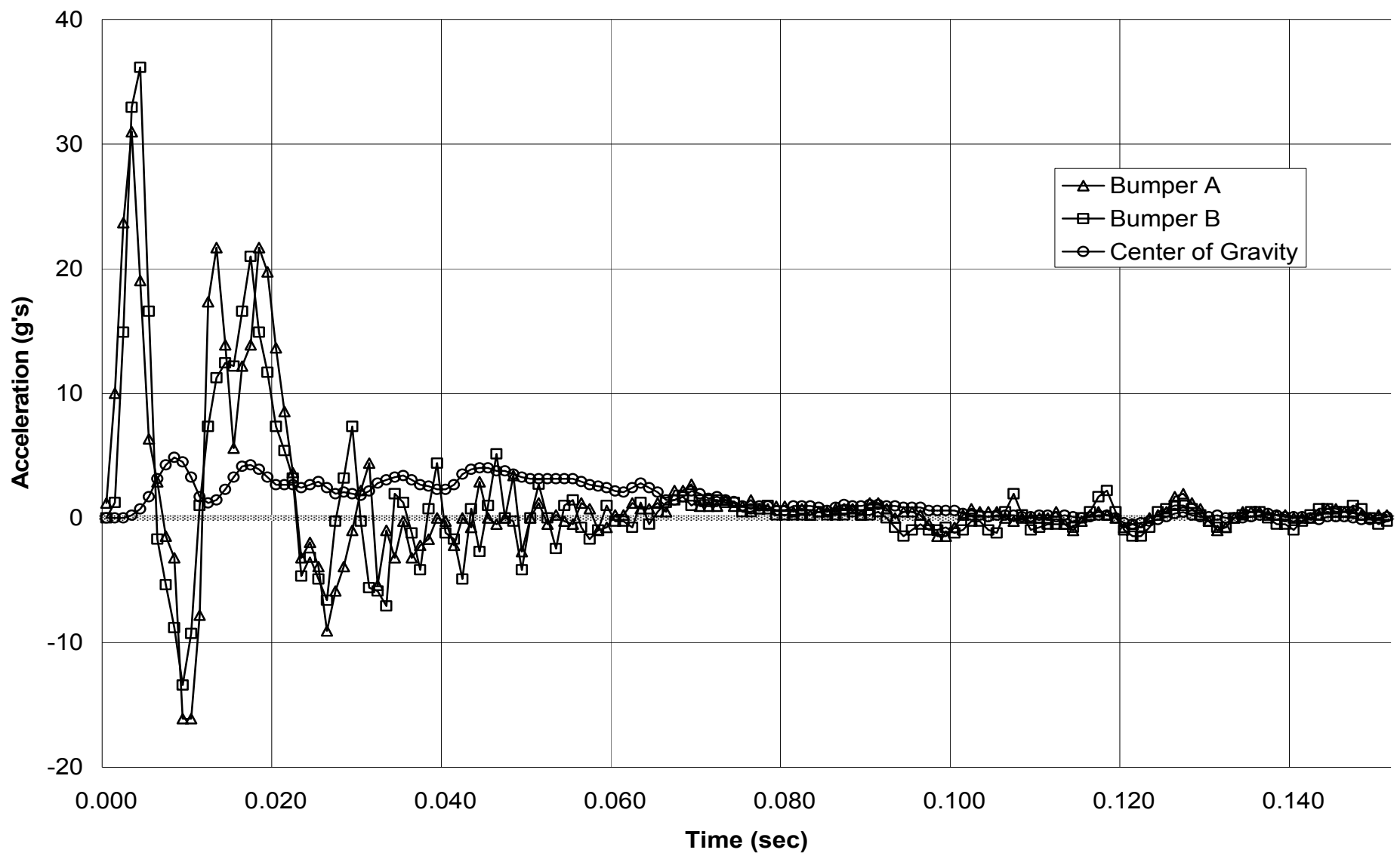

Figure 5-A Subject 3, test 1 (Torso Lean)

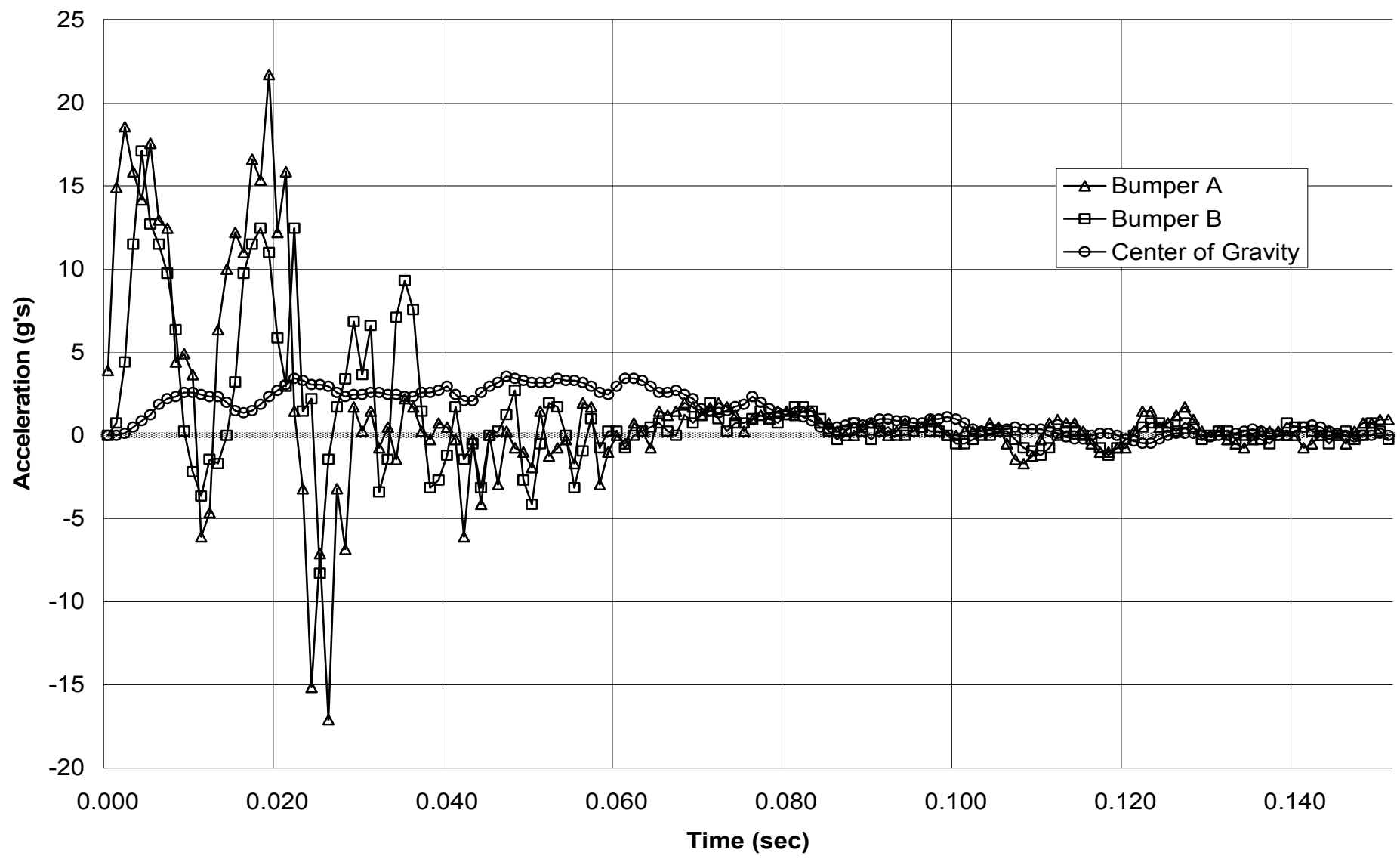

Figure 6-A Subject 3, test 2 (Normal) 


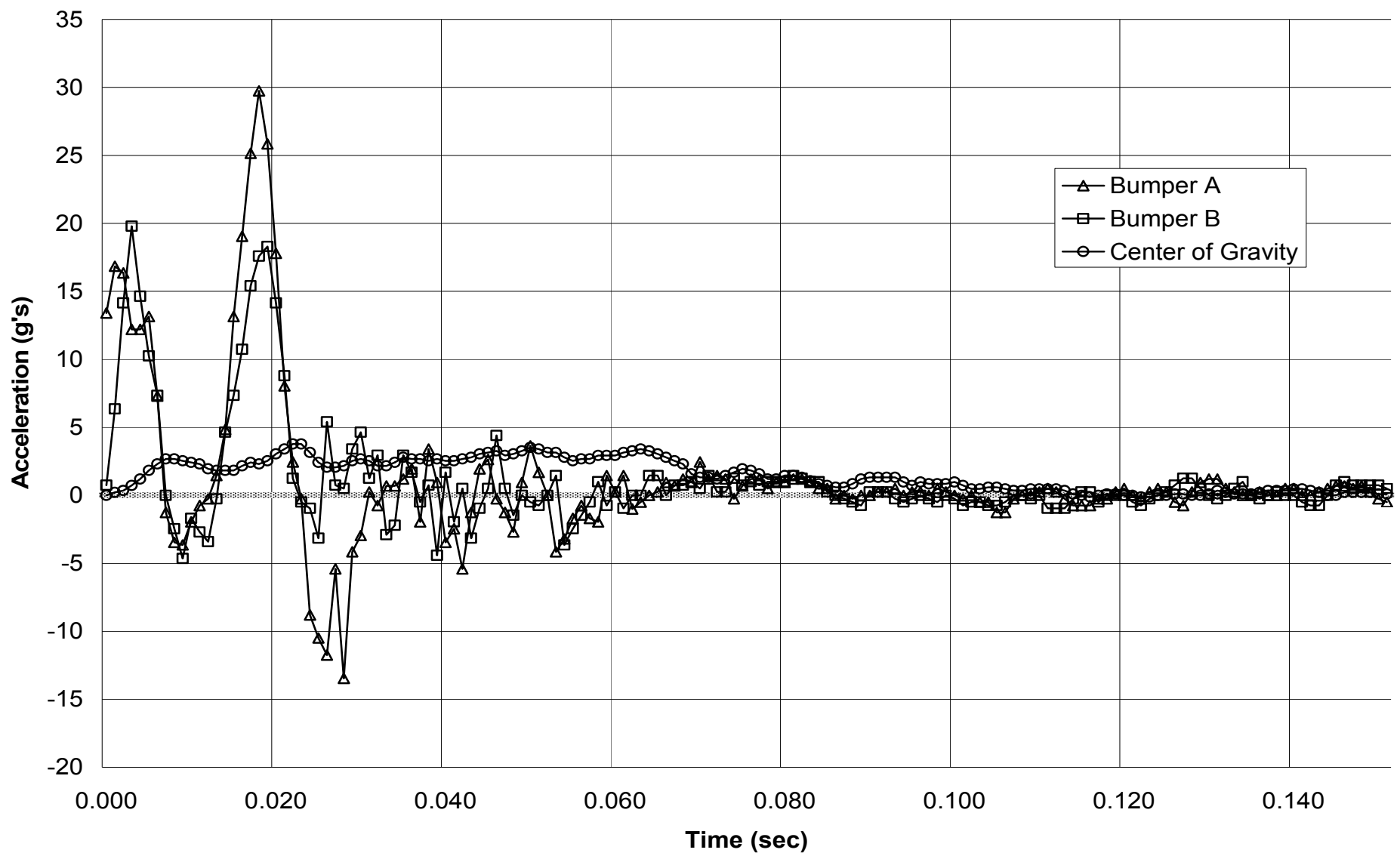

Figure 7-A Subject 3, test 3 (Head Flex / Torso Lean)

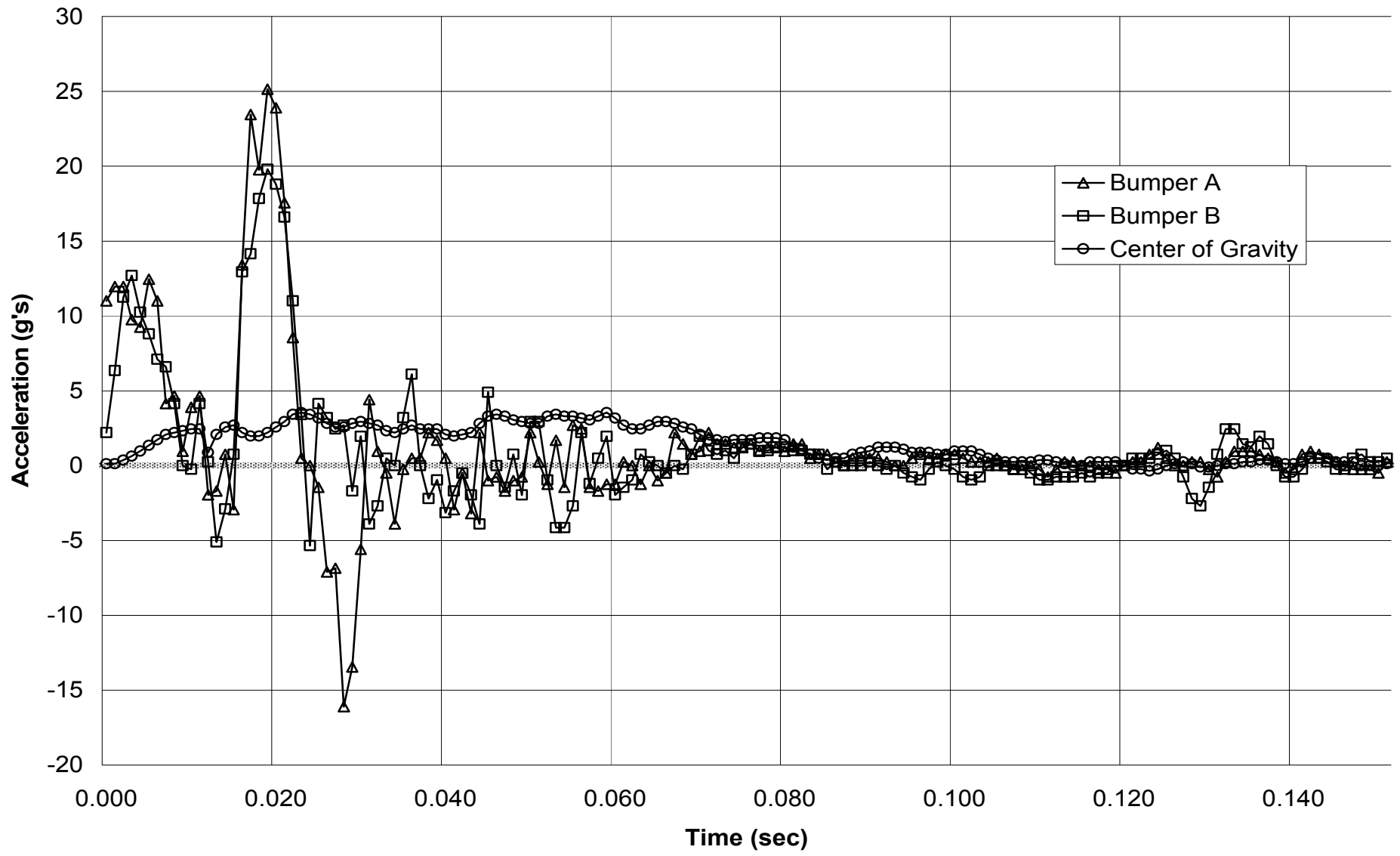

Figure 8-A Subject 3, test 4 (Head Flex) 


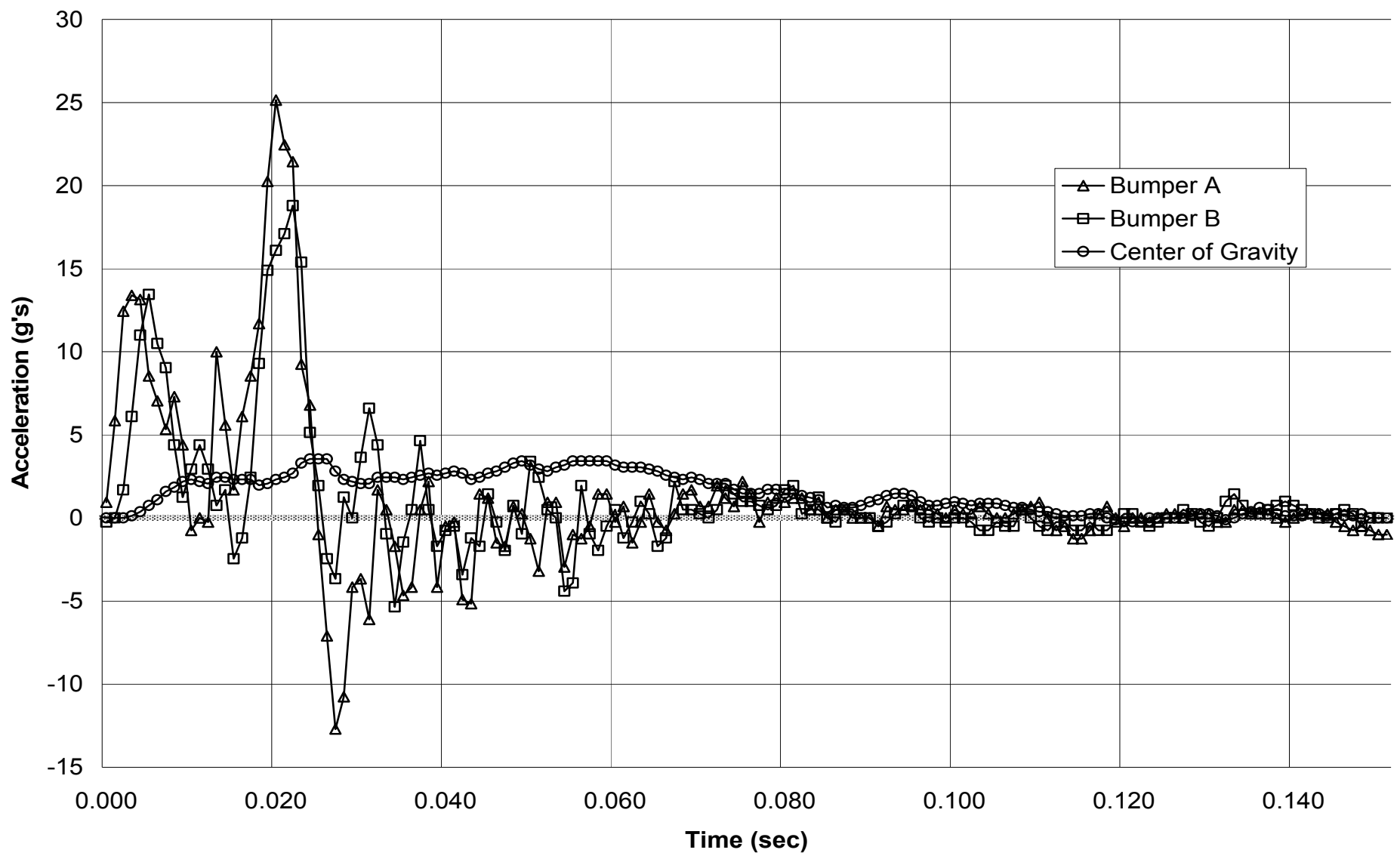

Figure 9-A Subject 4, test 1 (Normal)

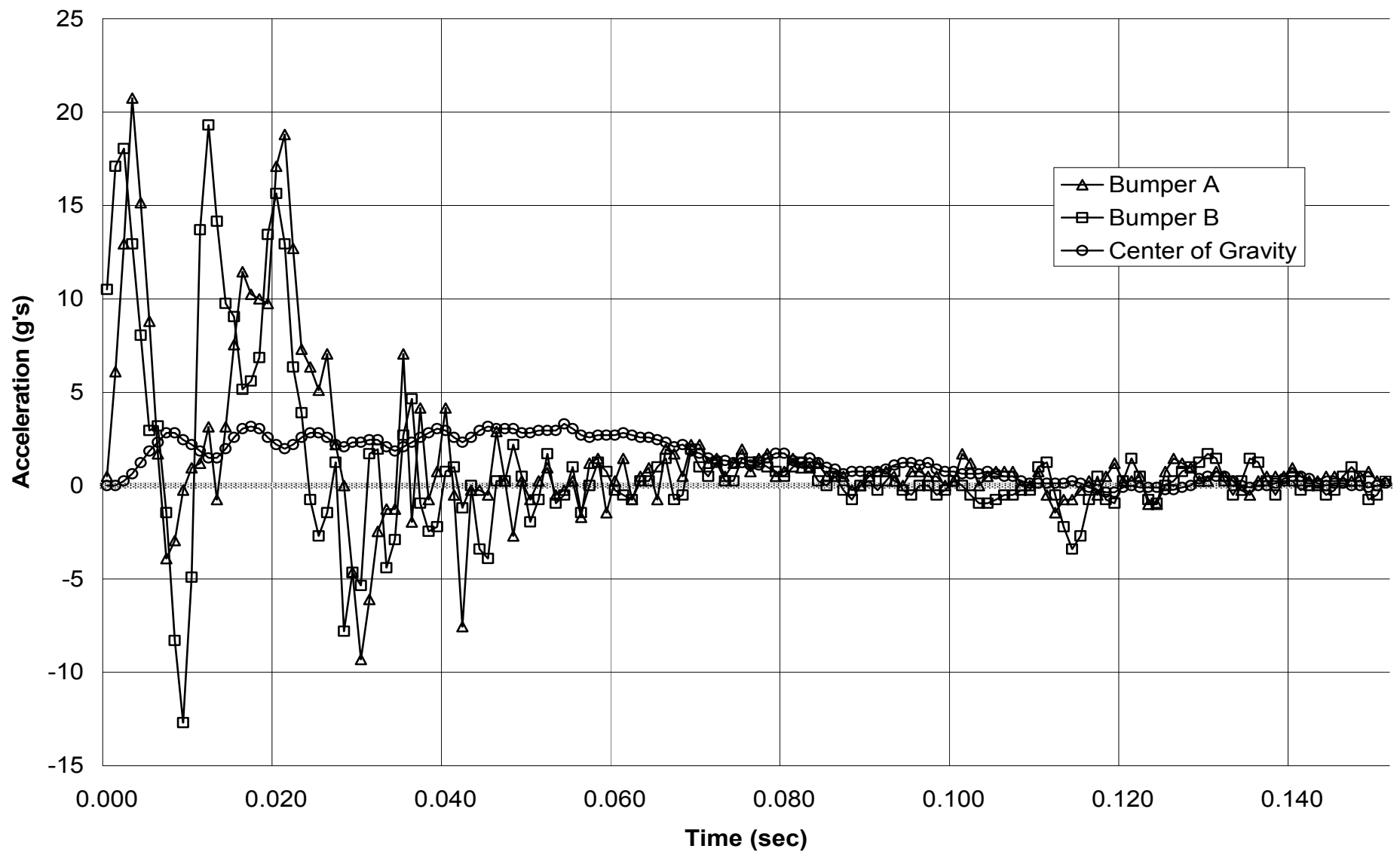

Figure 10-A Subject 4, test 2 (Head Flex / Torso Lean) 


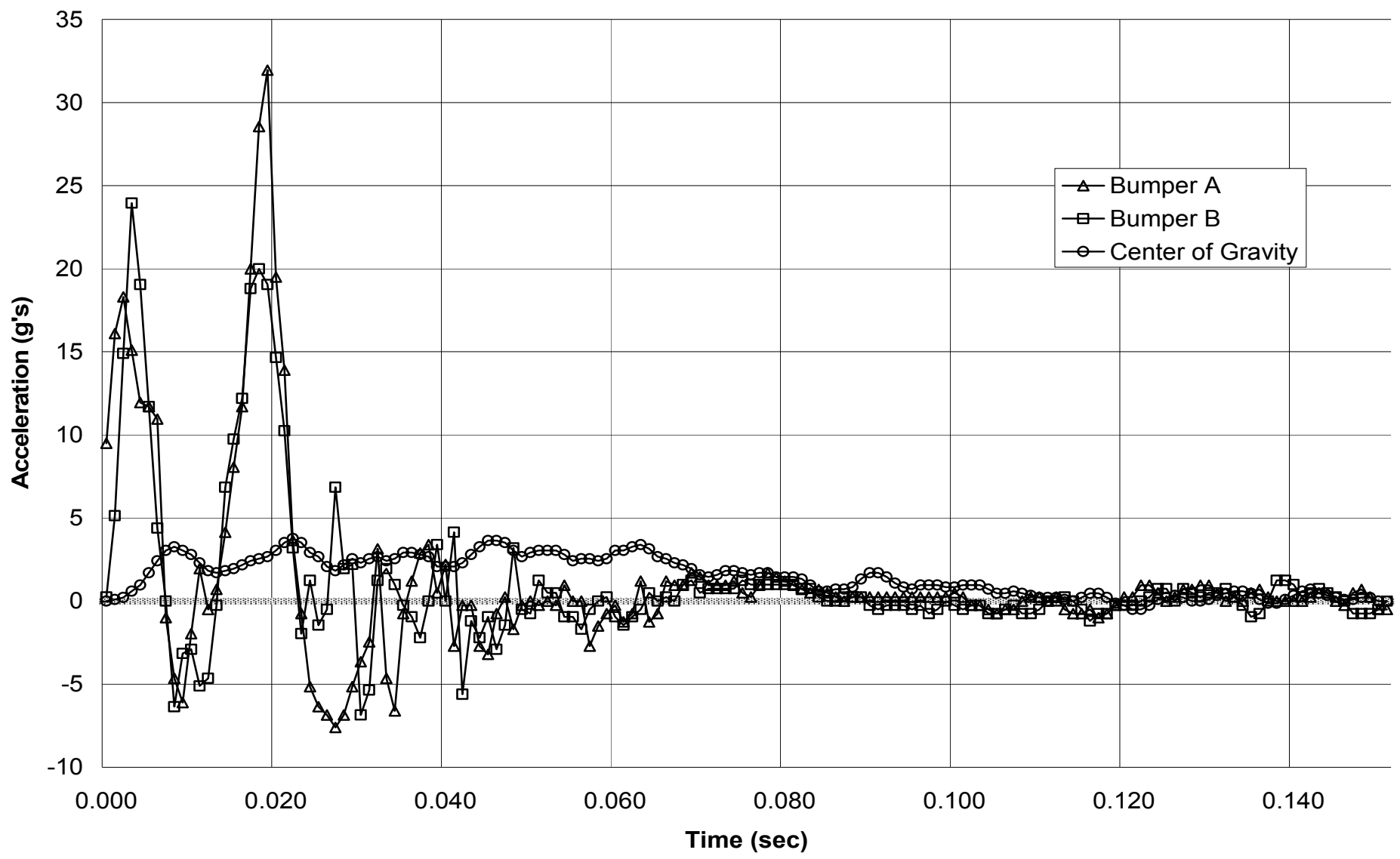

Figure 11-A Subject 4, test 3 (Head Flex)

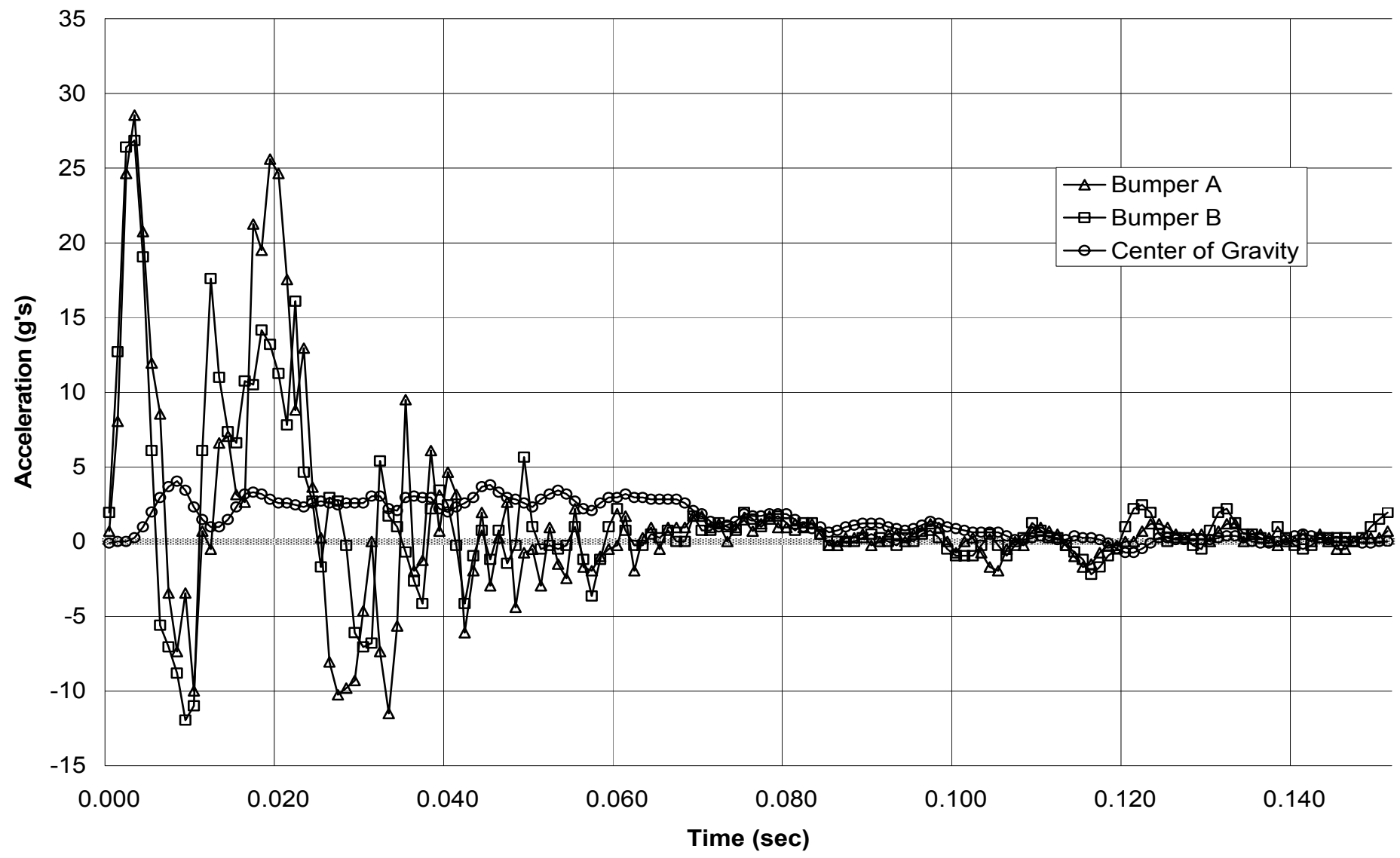

Figure 12-A Subject 4, test 4 (Torso Lean) 


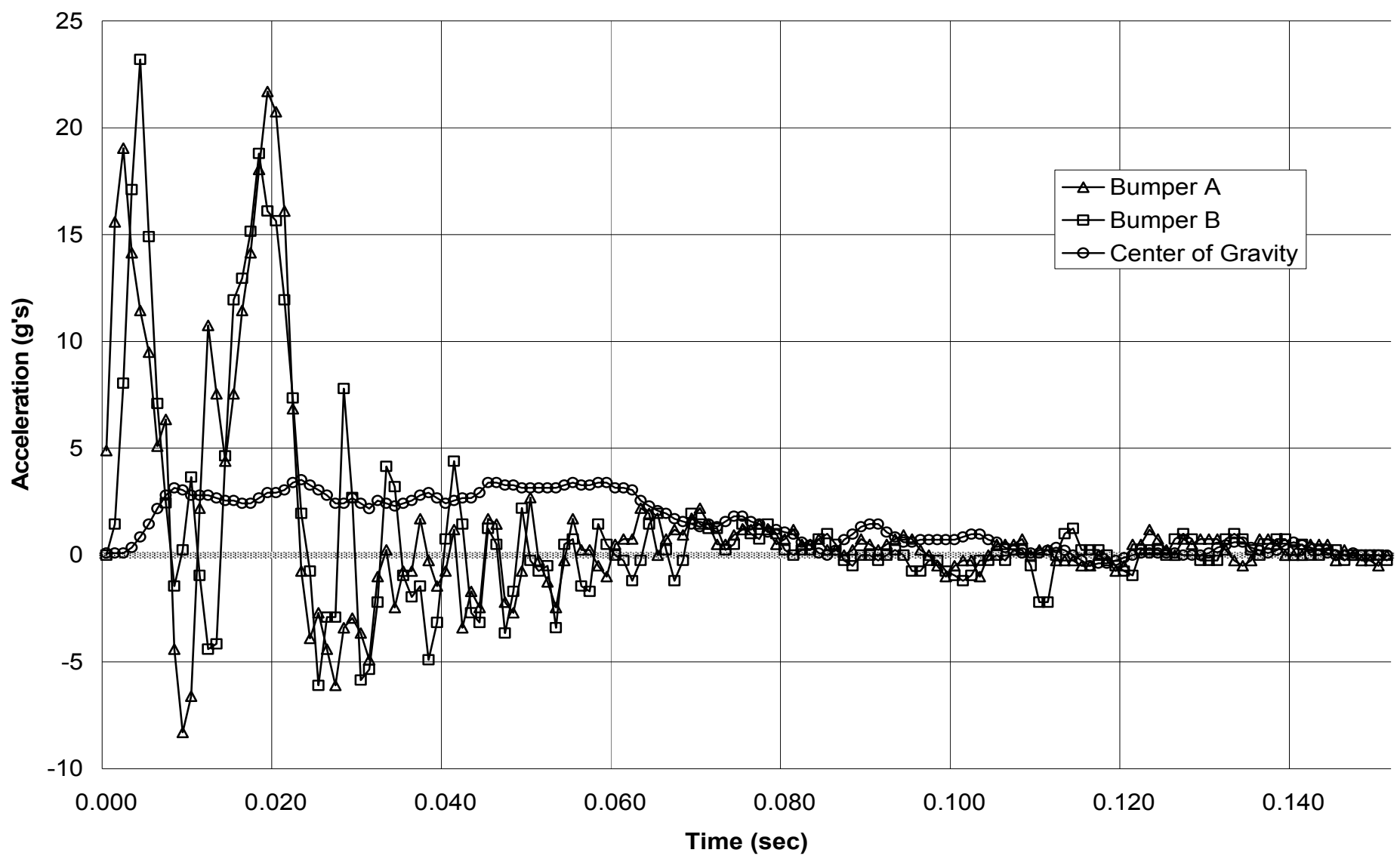

Figure 13-A Subject 5, test 1 (Head Flex)

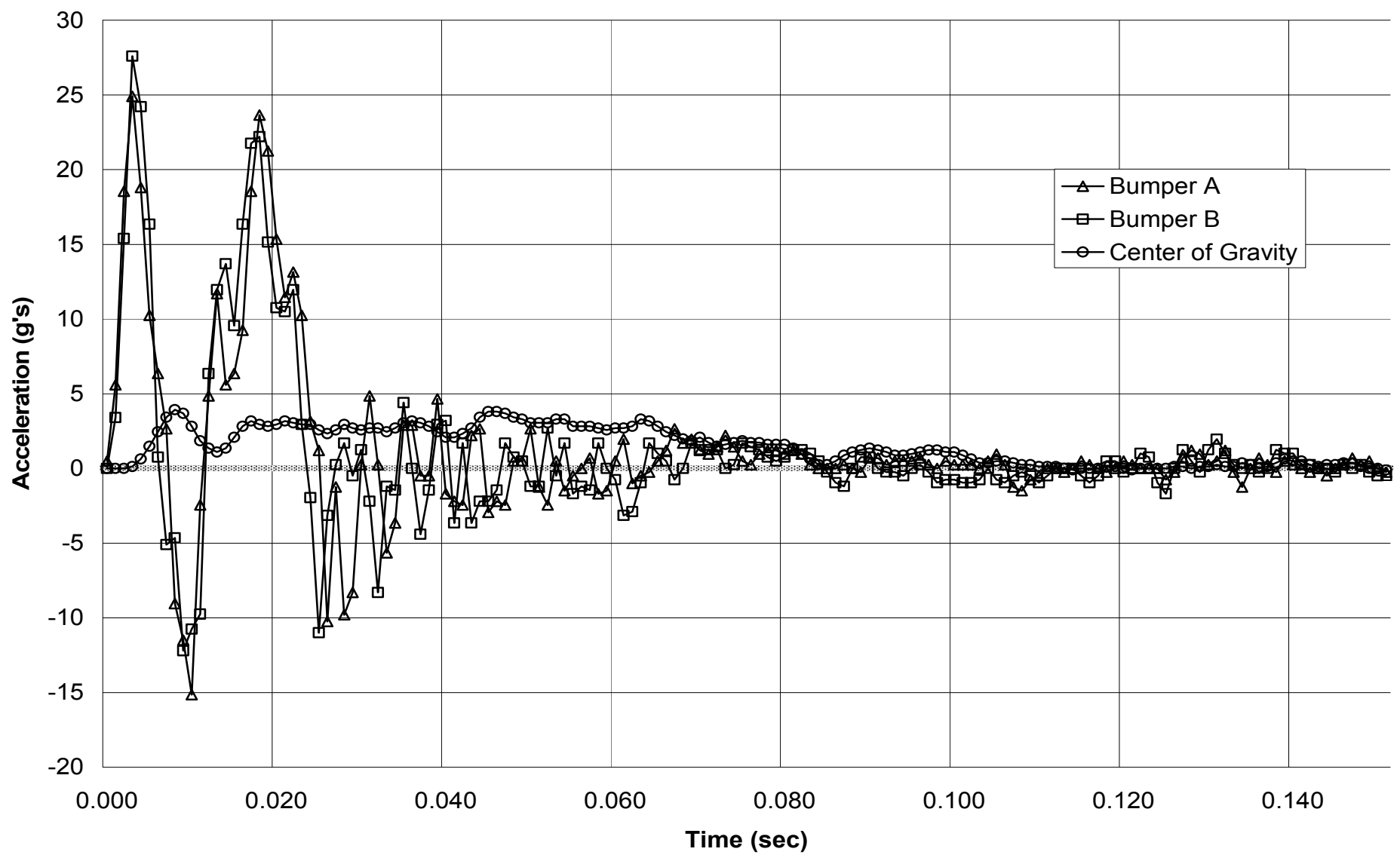

Figure 14-A Subject 5, test 2 (Torso Lean) 


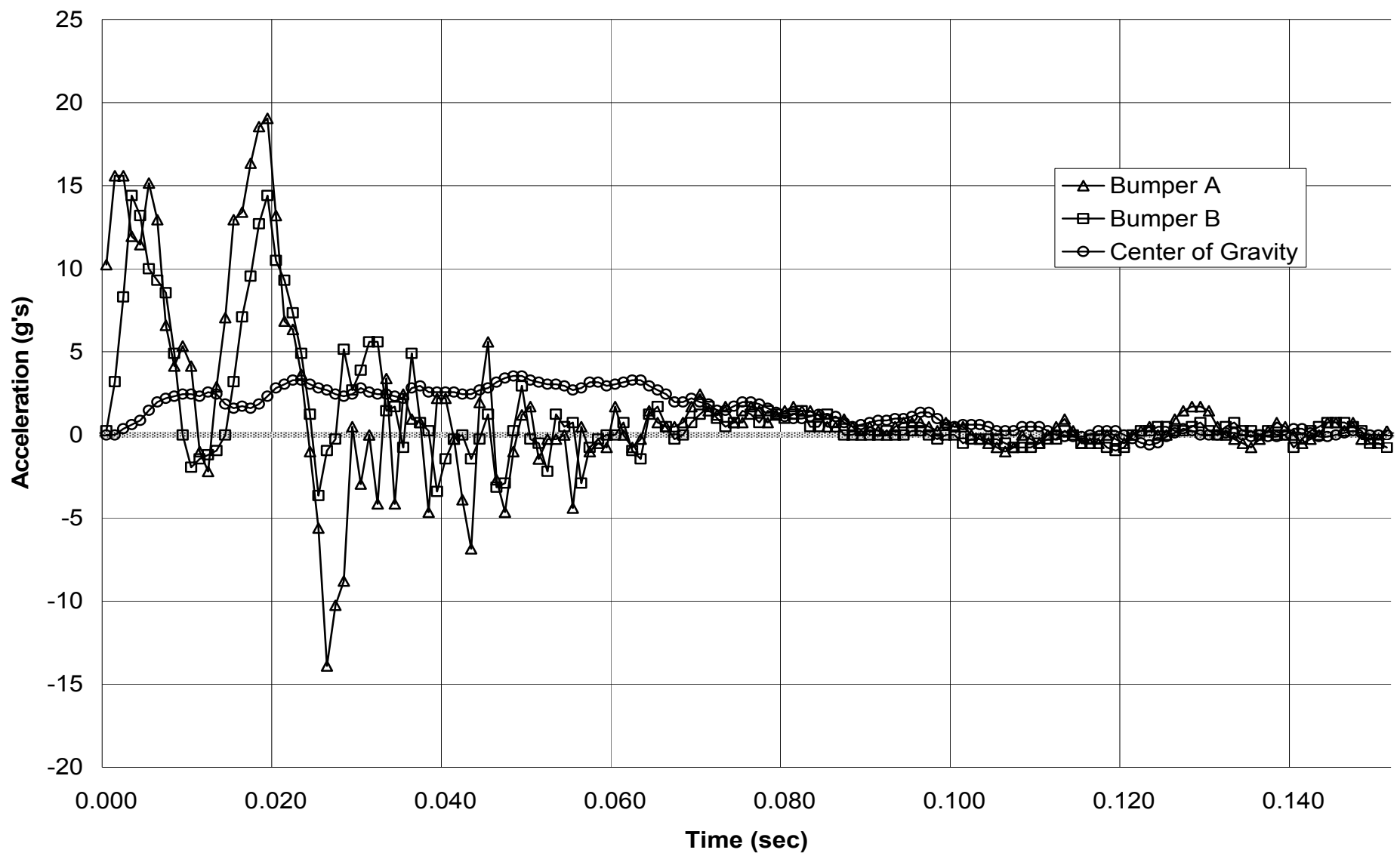

Figure 15-A Subject 5, test 3 (Normal)

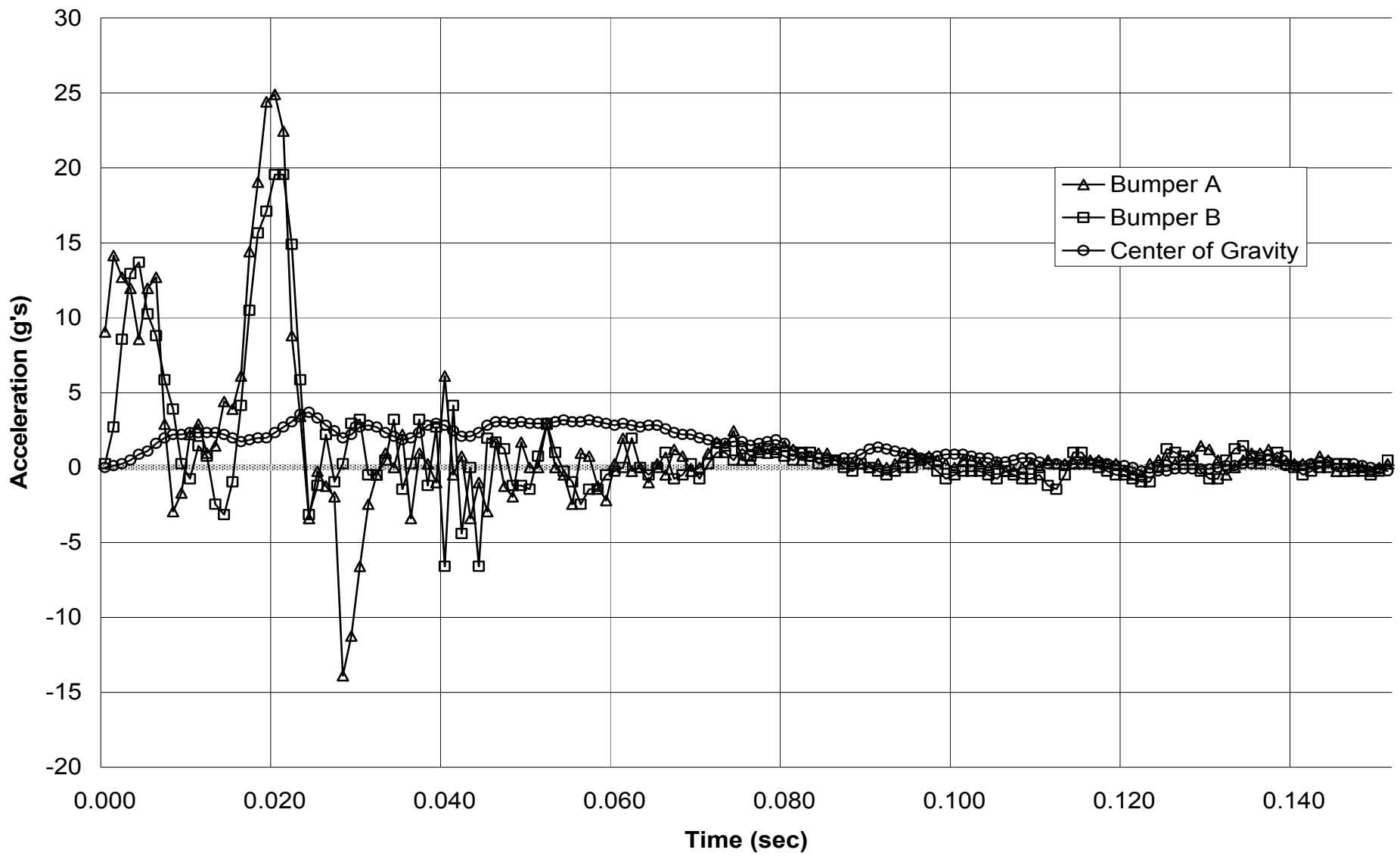

Figure 16-A Subject 6, test 1 (Torso Lean) 


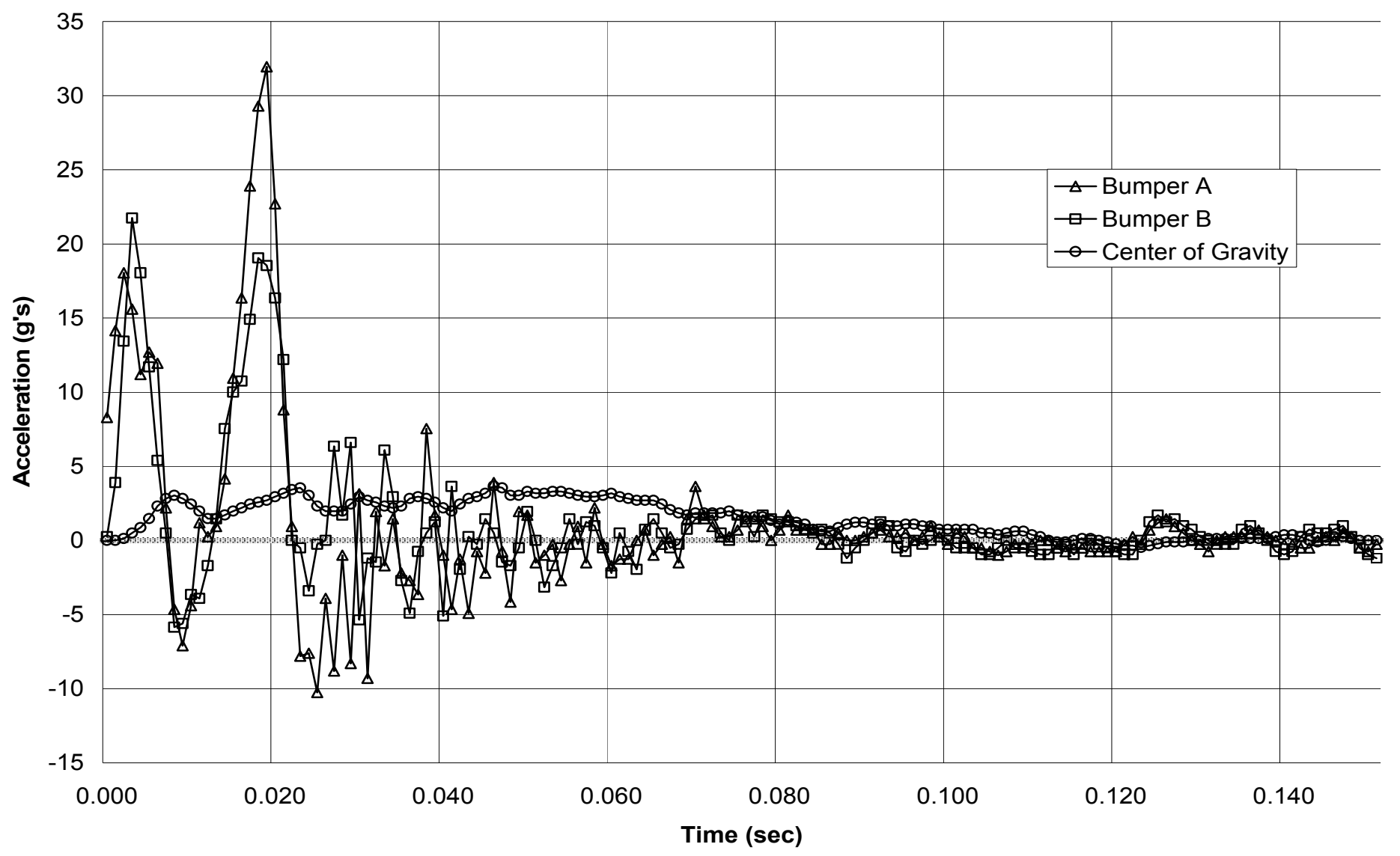

Figure 17-A Subject 6, test 2 (Normal) 
APPENDIX B

Combined sagittal plane head and chest acceleration data.

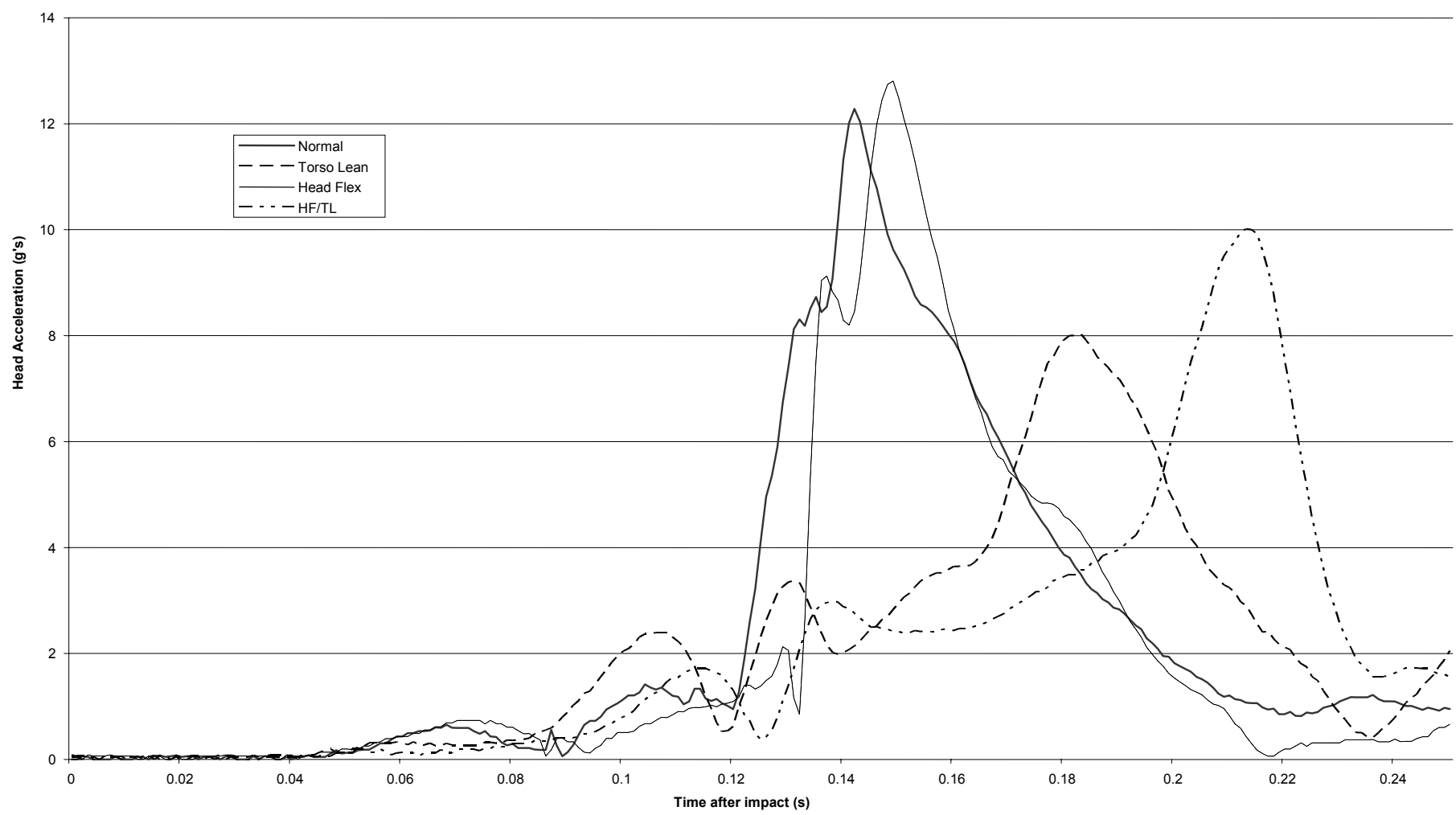

Figure 1-B Subject 1 (Head)

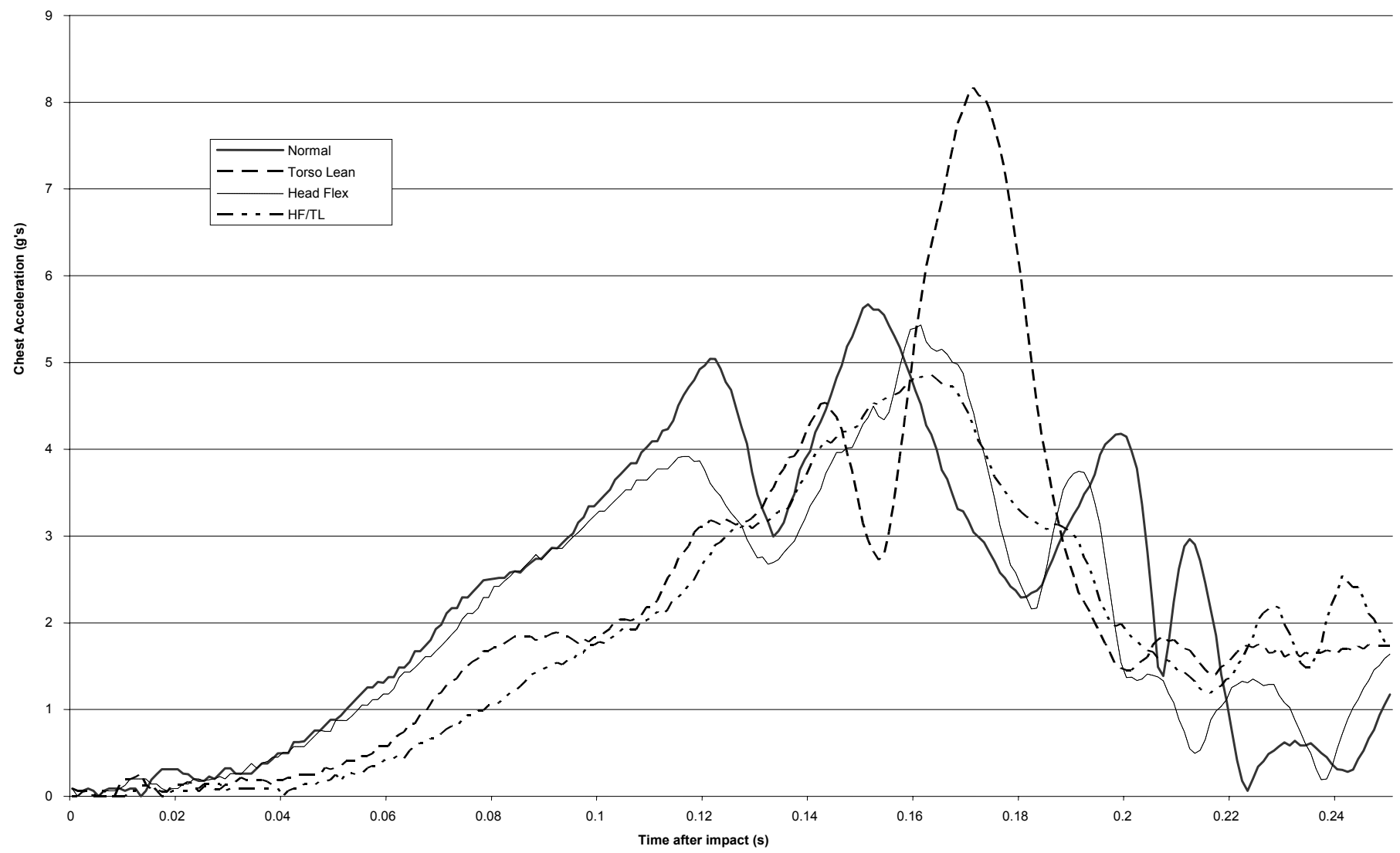

Figure 2-B Subject 1 (Chest) 


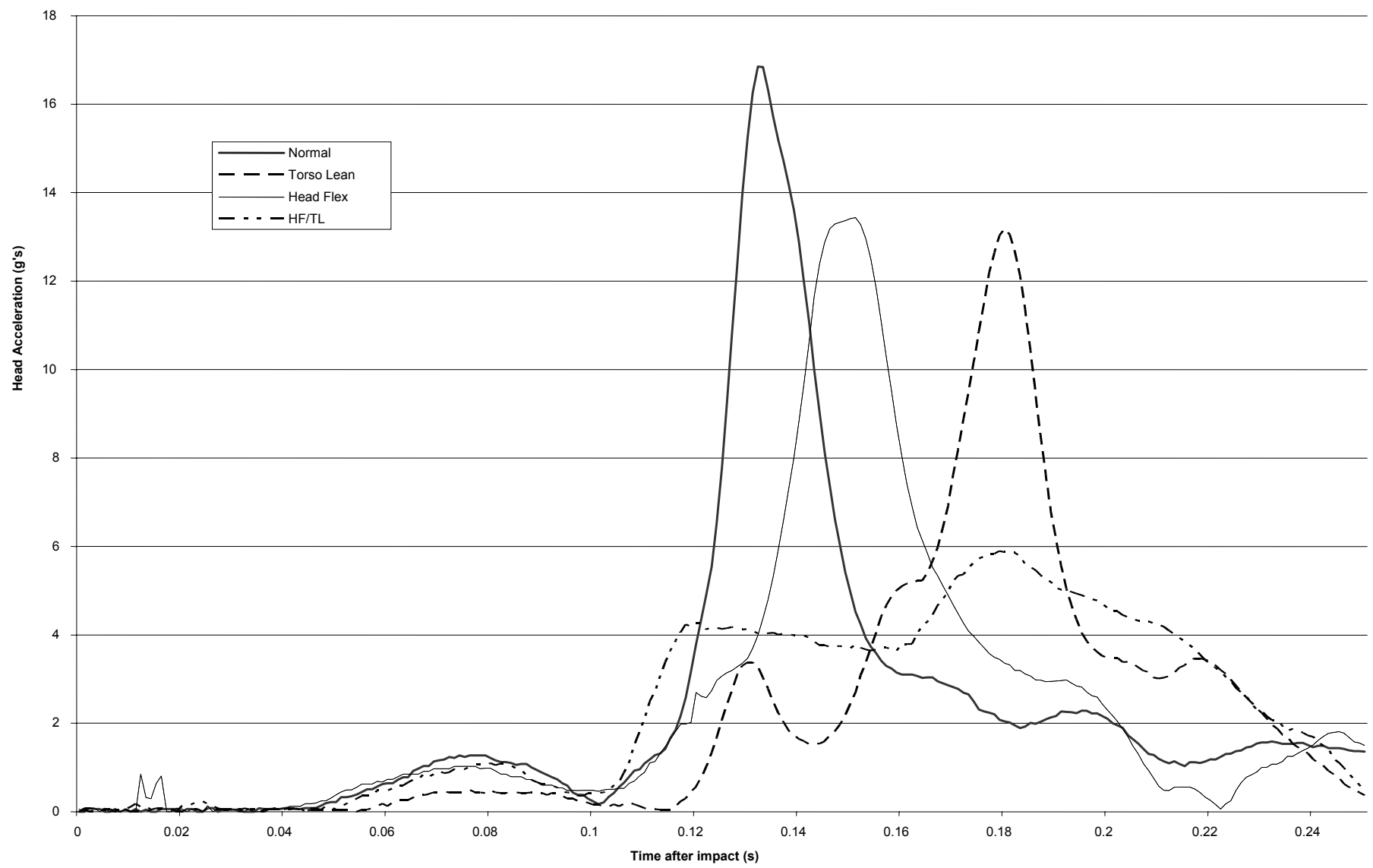

Figure 3-B Subject 3 (Head)

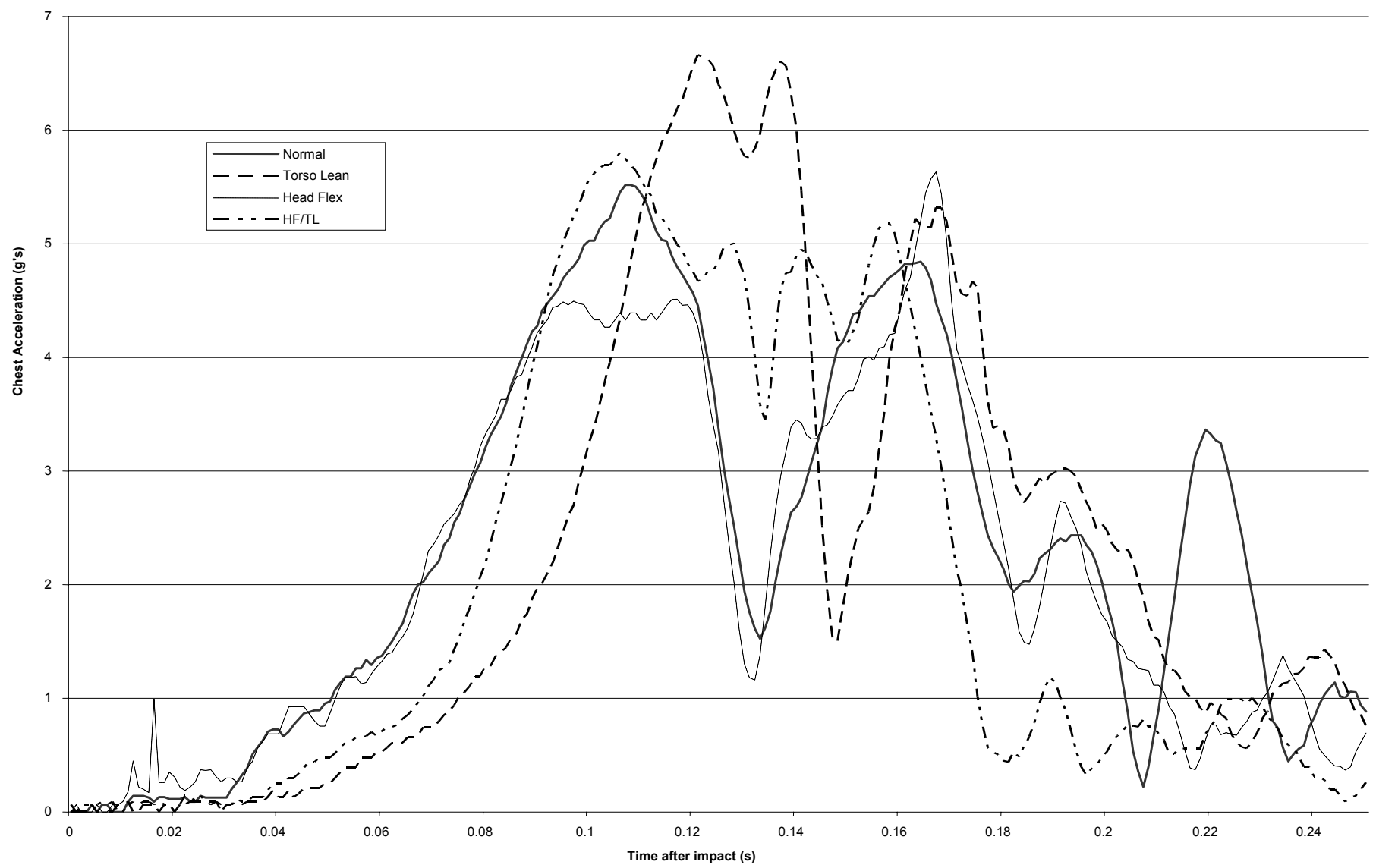

Figure 4-B Subject 3 (Chest) 


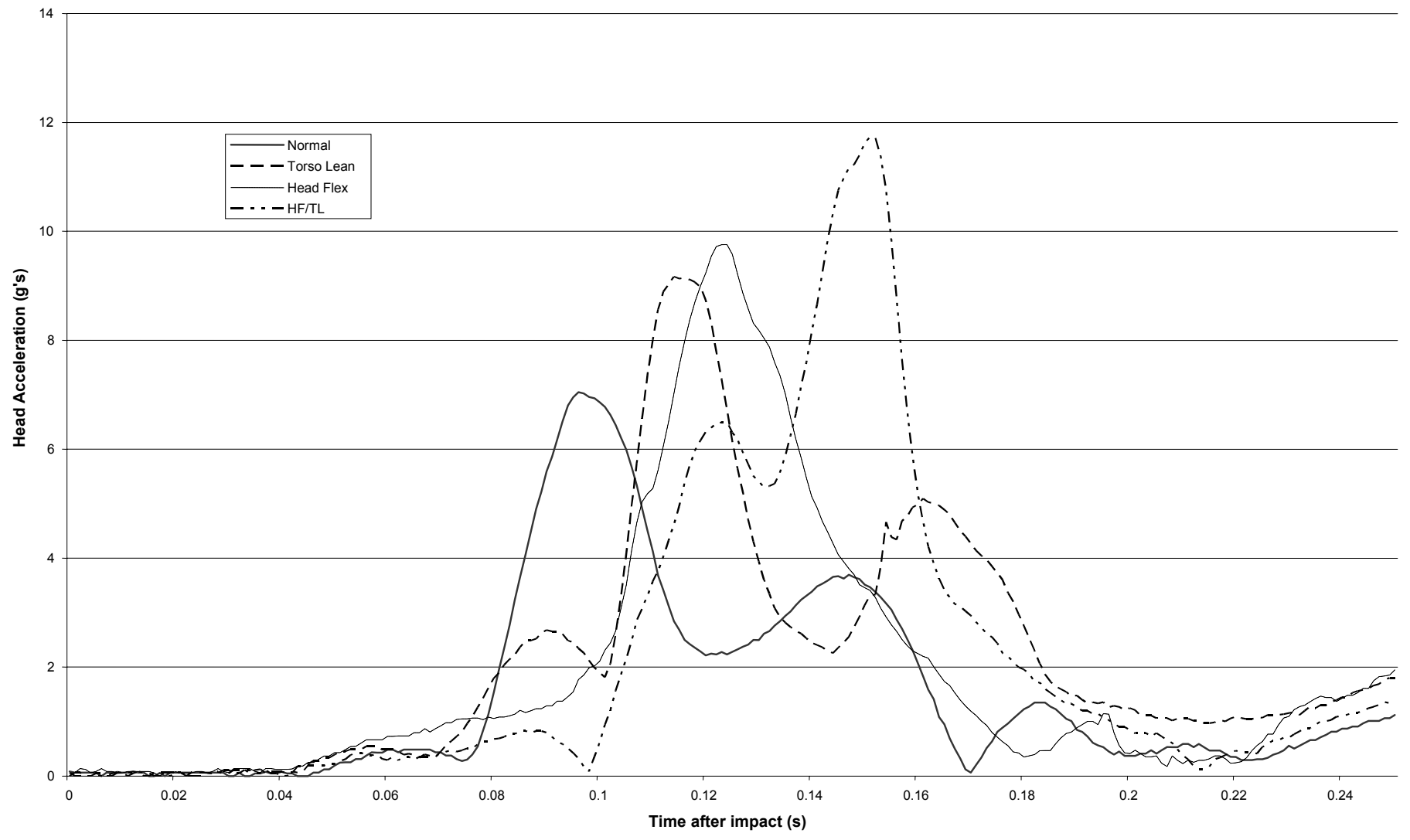

Figure 5-B Subject 4 (Head)

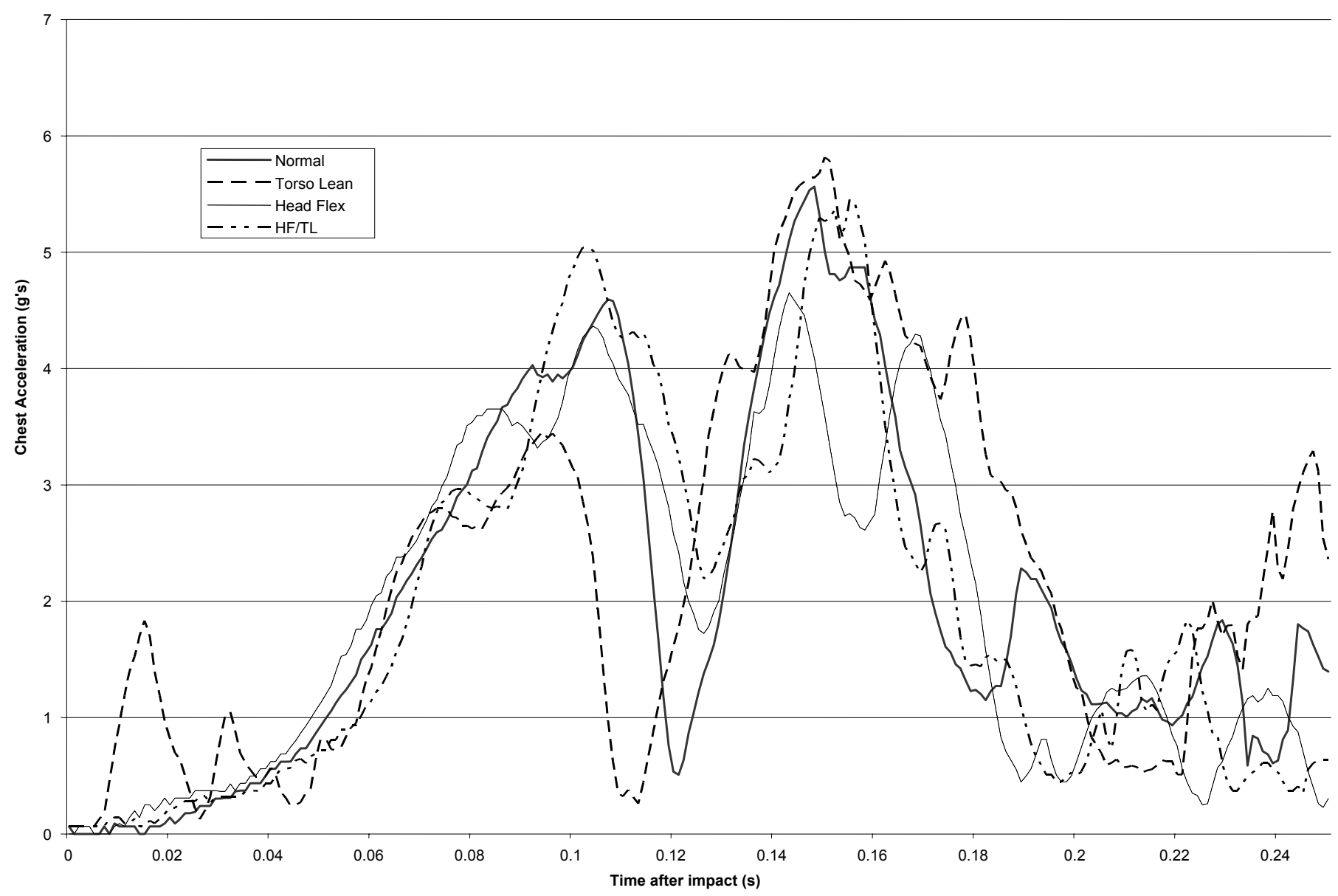

Figure 6-B Subject 4 (Chest) 


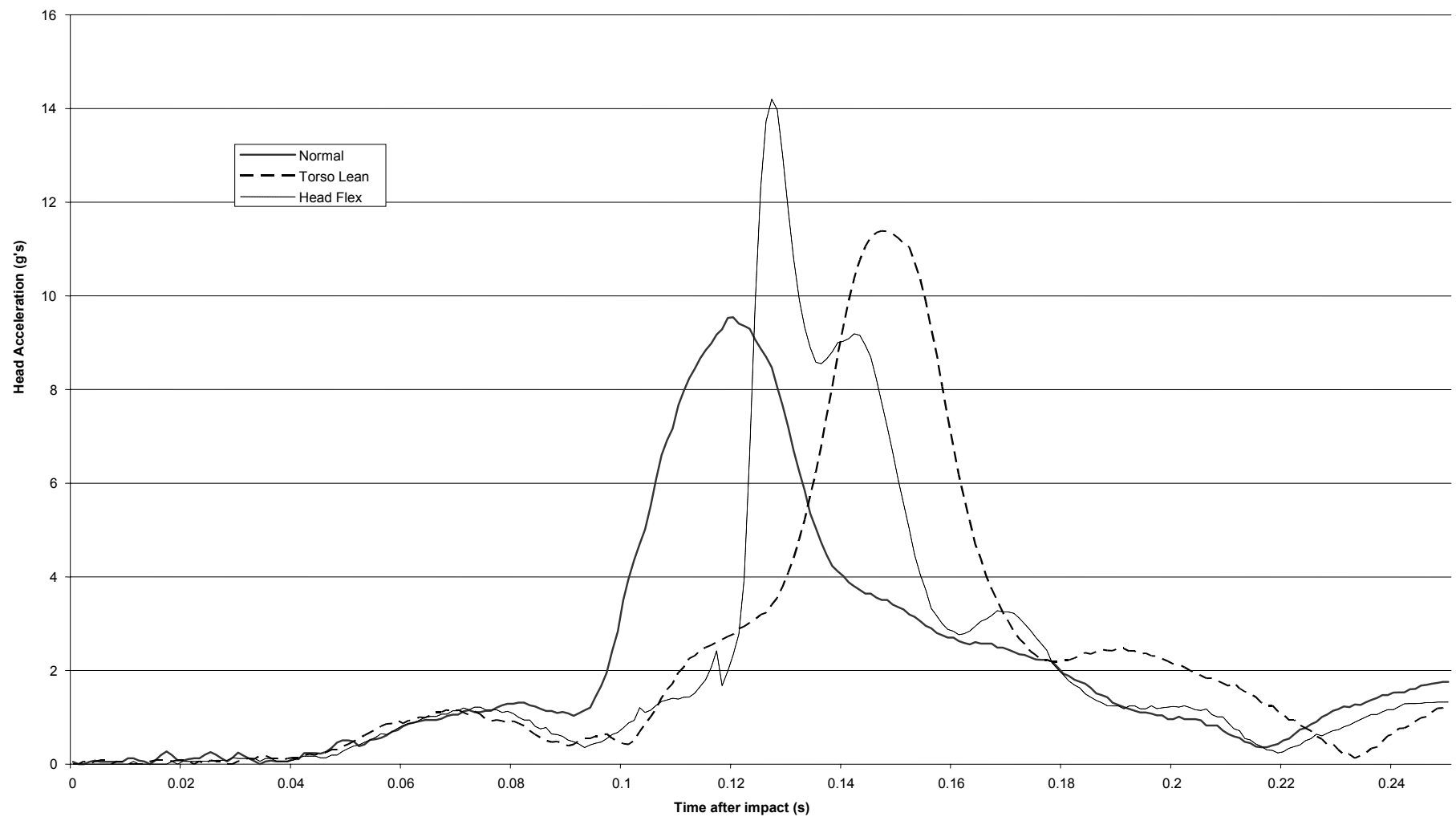

Figure 7-B Subject 5 (Head)

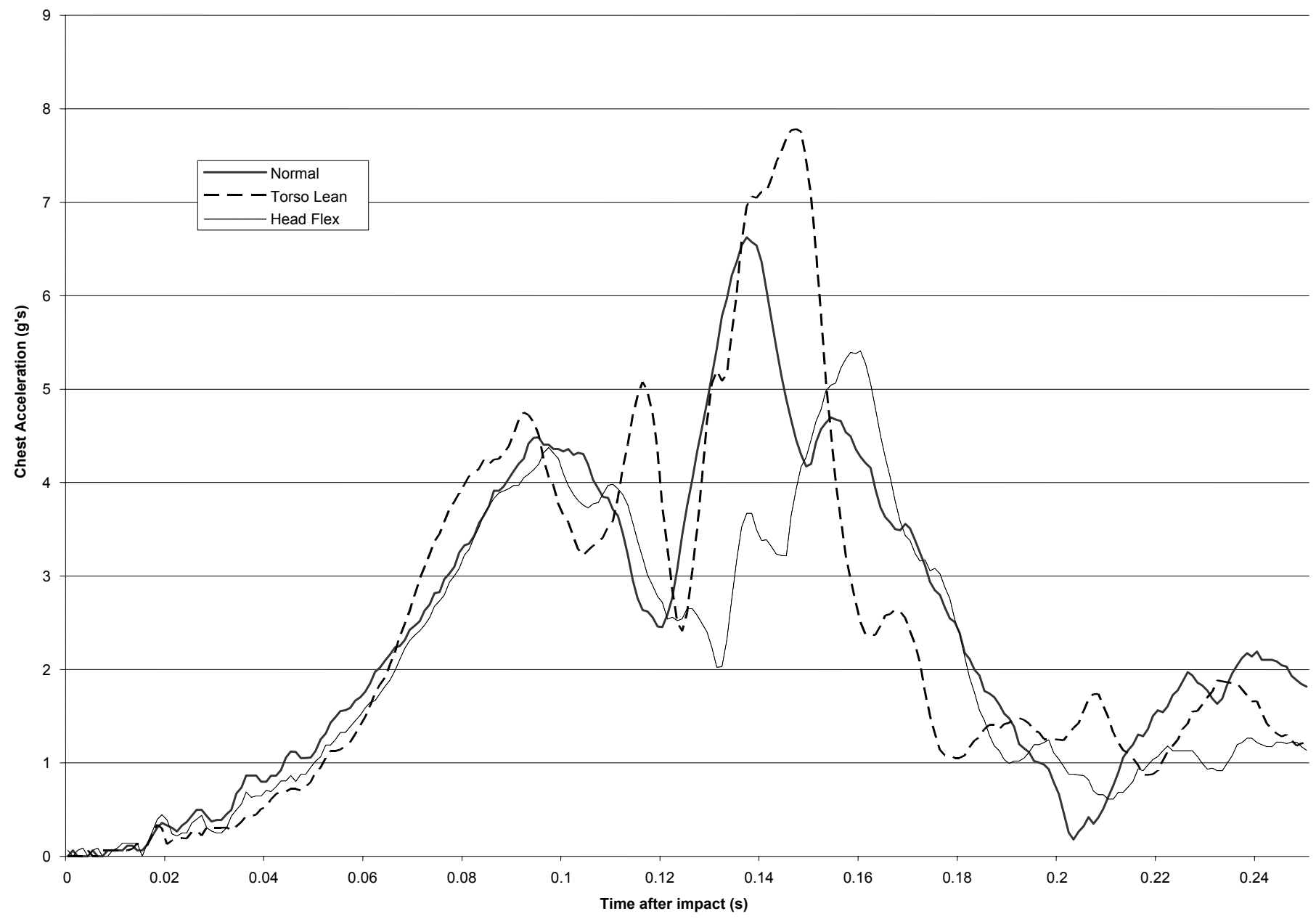

Figure 8-B Subject 5 (Chest) 


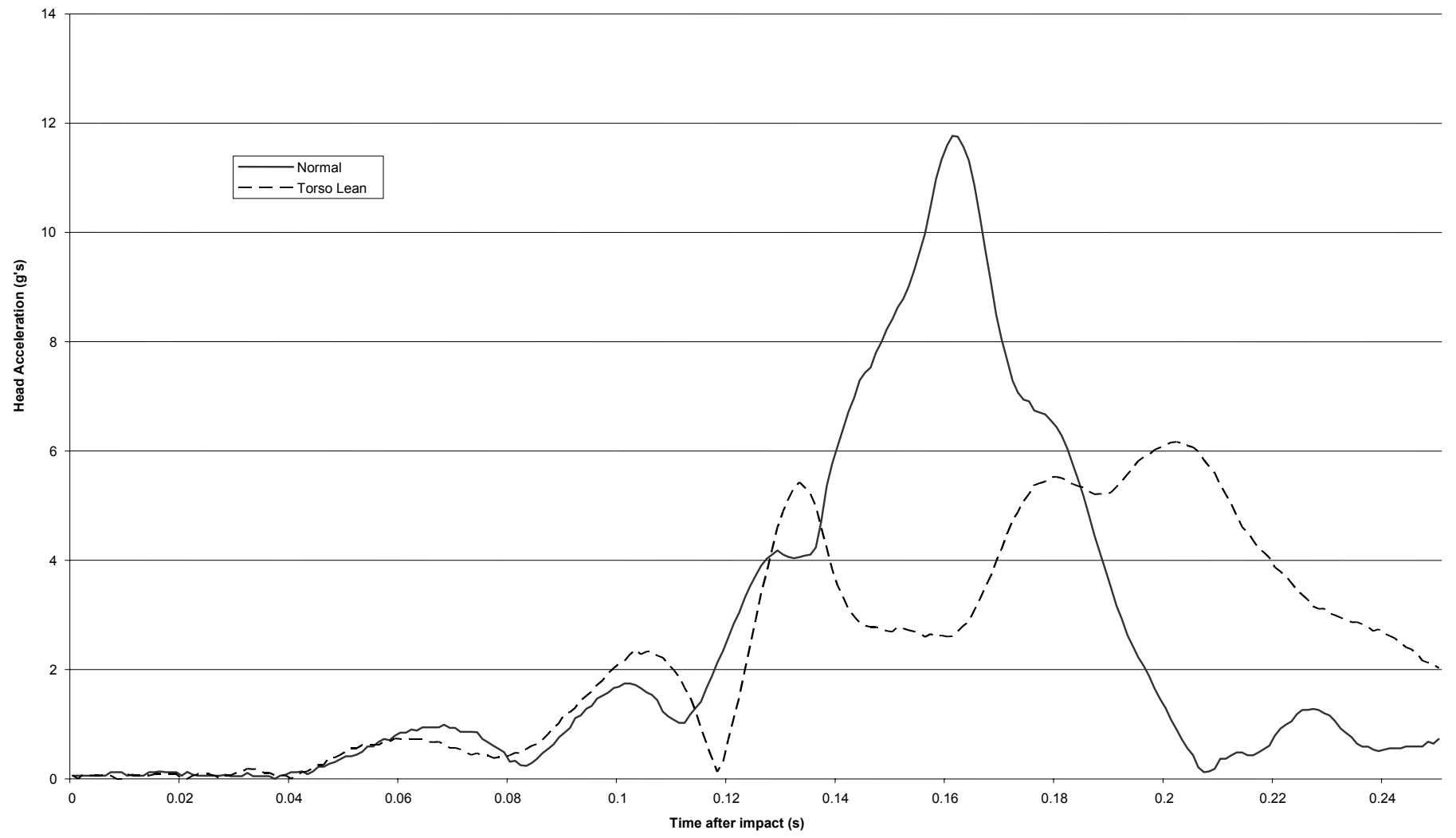

Figure 9-B Subject 6 (Head)

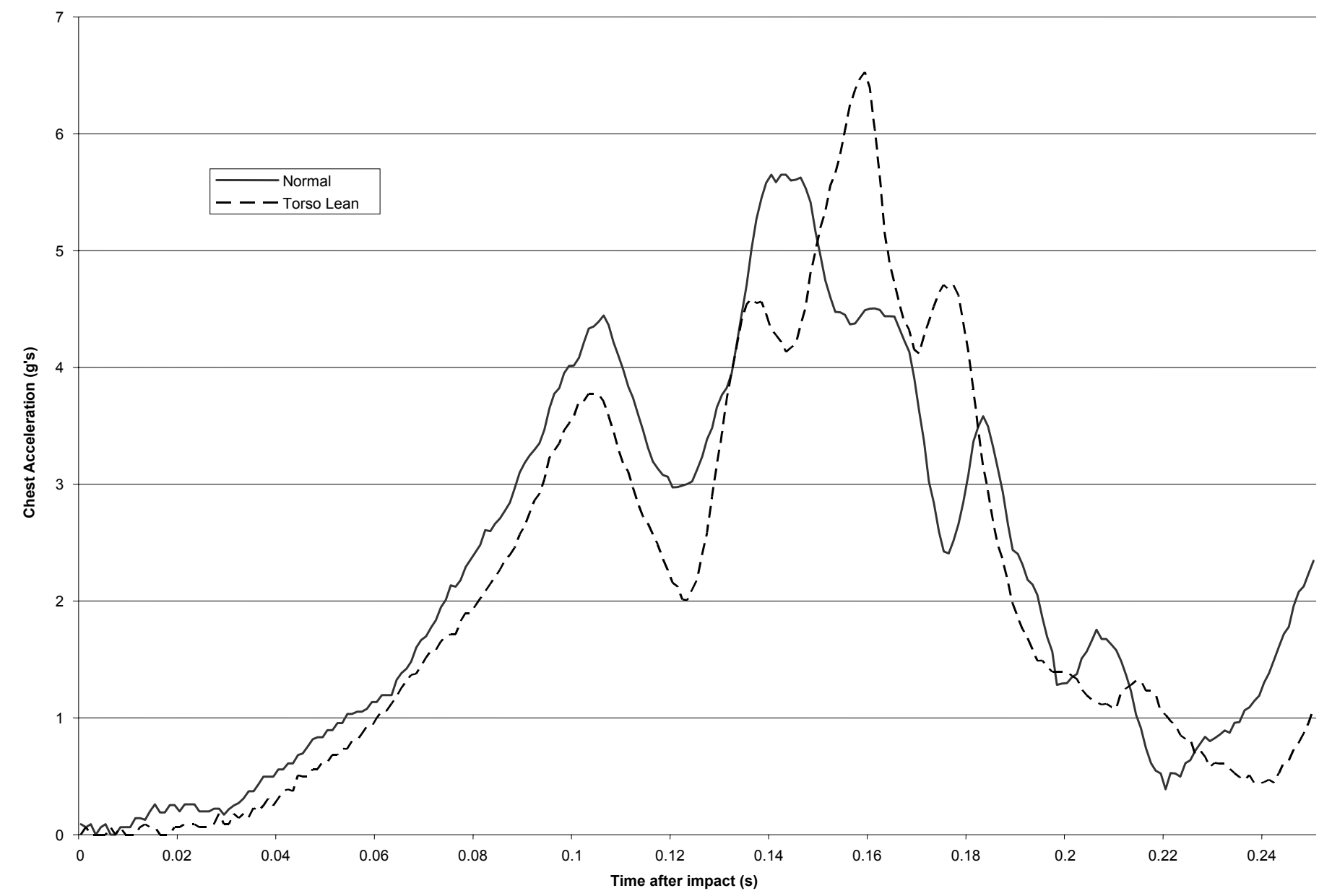

Figure 10-B Subject 6 (Chest) 